\title{
Amber- and plant-bearing deposits from the Cenomanian of Neau (Mayenne, France)
}

\author{
Didier Néraudeau ${ }^{1, *}$, Jean-Paul Saint Martin ${ }^{2}$, Simona Saint Martin ${ }^{2}$, Laurent Jeanneau ${ }^{1}$, \\ Jean-David Moreau ${ }^{3}$, Marc Philippe ${ }^{4}$, France Polette ${ }^{1,5}$, Damien Gendry ${ }^{1}$, John Brunet ${ }^{6}$ \\ and Jérôme Tréguier ${ }^{7}$ \\ ${ }^{1}$ Université de Rennes, UMR 6118, Géosciences Rennes, Campus de Beaulieu, avenue du Général Leclerc, 35042 Rennes, France \\ 2 Centre de Recherche en Paléontologie - Paris, UMR 7207, Muséum national d'Histoire naturelle, Sorbonne Université, CNRS, 8, \\ rue Buffon, 75005 Paris, France \\ ${ }^{3}$ Université de Bourgogne Franche-Comté, UMR 6282, Biogéosciences, 6, boulevard Gabriel, 21000 Dijon, France \\ ${ }^{4}$ Université de Lyon I and LEHNA, UMR 5023, 69622 Villeurbanne, France \\ 5 Department of Geology, University of Namur, ILEE, Institute of Life, Earth and Environment, 61, rue de Bruxelles, 5000 Namur, \\ Belgium \\ 6 5, rue de Bellevue, 35220 Marpiré, France \\ ${ }^{7}$ Musée des Sciences, 21, rue du Douanier Rousseau, 53000 Laval, France
}

Received: 20 May 2020 / Accepted: 28 September 2020

\begin{abstract}
A new Cenomanian amber- and plant-bearing deposit has been discovered at Neau, in the Mayenne department (France). The Cenomanian fossiliferous lignites are located in karst filling in a substratum of Cambrian limestones. The amber corresponds mainly to tiny millimetric grains, devoid of arthropod inclusions, but rich in microorganisms, especially the sheated bacteria Leptotrichites resinatus, and containing pollen grains (Classopollis) and wood fibers (Araucariacae or Cheirolepidiaceae). The lignites provide abundant conifer and ginkgoale cuticle fragments (Frenelopsis, Eretmophyllum) and a lot of palynomorphs (e.g. Gleicheniidites senonicus, Cyathidites, Deltoidospora, Appendicisporites and Cicatricosisporites). The chemical signature of the amber suggests it was produced by conifers of the extinct family Cheirolepidiaceae. According to the palynological assemblage, the age of the lignites is upper lower Cenomanian or lower mid Cenomanian. The deposit environment corresponded to the upstream portion of a mangrove or the most inner part of a lagoon.
\end{abstract}

Keywords: Palynology / Gymnosperm cuticles / Cheirolepidiaceae / Sheated bacteria / Amber / Cenomanian / France

Résumé - Le site à ambre et plantes du Cénomanien de Neau (Mayenne, France). Un nouveau site à ambre et plantes du Cénomanien a été découvert à Neau, en Mayenne (France). Les lignites fossilifères cénomaniens sont localisés dans des remplissages de karsts développés dans des calcaires du Cambrien. L'ambre se présente essentiellement sous forme de grains millimétriques, dépouvus d'inclusions d'arthropode, mais riches en microorganismes, notamment en bactéries gainées de type Leptotrichites resinatus, et contenant des grains de pollen (Classopollis) et des fibres de bois (Araucariacae ou Cheirolepidiaceae). Les lignites fournissent d'abondants fragments de cuticules de conifères et de ginkgoales (Frenelopsis, Eretmophyllum) et une grande quantité de palynomorphes (e.g. Gleicheniidites senonicus, Cyathidites, Deltoidospora, Appendicisporites et Cicatricosisporites). La signature chimique de l'ambre suggère qu'il a été produit par des conifères de la famille éteinte des Cheirolépidiacées. D'après l'assemblage palynologique, l'âge des lignites est Cénomanien inférieur tardif ou Cénomanien moyen basal. L'environnement de dépôt correspondait à la partie amont d'une mangrove ou la partie la plus interne d'un lagon.

Mots clés : Palynologie / Cuticules de gymnospermes / Cheirolepidiaceae / Bactéries gainées / Ambre / Cénomanien / France

\footnotetext{
*Corresponding author: didier.neraudeau@univ-rennes1.fr
} 


\section{Introduction}

Late Cretaceous amber deposits are well distributed in western France, from the Anjou and Sarthe regions, at the North, (Ecommoy locality in Girard et al., 2013a, 2013b; Hucheloup locality in Fleury et al., 2017) to the Aude department, at the South (Fourtou locality in Girard et al., 2013a, 2013b; see Moreau et al., 2017, for a synthetic map of mid-Cretaceous french amber deposits). The more numerous amber deposits and the more rich in amber are located in the Charentes region, where Cenomanian sands and clays with lignite have been studied in several quarries, road works and coastal outcrops (Néraudeau et al., 2002, 2003, 2005, 2008). Conversely, amber from Mayenne has been the less studied. The only previous works were made by Durand and Louail (1971) about the discovery of a karst filling of fossiliferous Cenomanian lignites and sands in a substratum of Cambrian limestones at Neau, and by Azema et al. (1972) who performed a palynological analysis of the sediment. The latter study described lower to mid Cenomanian assemblages dominated by gymnosperm pollen grains and fern spores, and marked by the progressive increase of angiospermous forms. Finally, the rare mentions of Cenomanian amber at Neau have been provided by Durand and Louail (1971), and the few available data were then cited by other authors, such as Girard et al. (2013a, 2013b). We present here the first synthesis dedicated to the Cenomanian amber from Neau and its associated botanical macro-, meso- and microremains, along with palaeoenvironmental and stratigraphic considerations.

\section{Material and methods}

\subsection{Field observations}

The Neau quarry is located at about $30 \mathrm{~km} \mathrm{NW}$ from Laval in the department of Mayenne, NW France (Fig. 1). The quarry is exploited by the Society Chaux \& Dolomie Françaises/ Lhoist France Ouest for the extraction of Cambrian dolomitic limestones and the production of lime.

At the top of the Cambrian limestones, several dissolution cavities are filled by Cenomanian erosive deposits (Figs. 2 and 3). According to the field observations made by the authors, the base of the karsts corresponds generally to a few metres of lignitic sand and clay ( $\mathrm{CnL}$ facies on Figs. 2A and 3) including large pieces of fossil wood (trunk and branches fragments). The top of the karst filling consists of one to two metres of white sand ( $\mathrm{CnS}$ facies on Figs. 2A and 3A-B), more or less oxidized and coloured in yellow at the contact with the lignite. Both Cambrian limestone palaeoreliefs and karsts are covered by discordant glauconitic sands $(\mathrm{CnG}$ facies on Figs. 2A and $3 \mathrm{~A}-\mathrm{B}$ ) including more or less kaolinitic lenses. The base of lignitic deposits contains pyritised foraminifers that testify the coastal marine origin of these sediments (Durand and Louail, 1971). The marine remains disappear at the top of the Cenomanian sandy deposits. The presence of kaolinite indicates a typical lateritic weathering anterior to the Cenomanian (Durand and Louail, 1971). One sample of lignitic clay has been collected at the top of the facies $\mathrm{CnL}$ in the main karst (Fig. 3A-B), for palynological analyses. In addition, seven samples recovered from Neau amber-rich lignitic clay in 1972, and 39 corresponding palynological

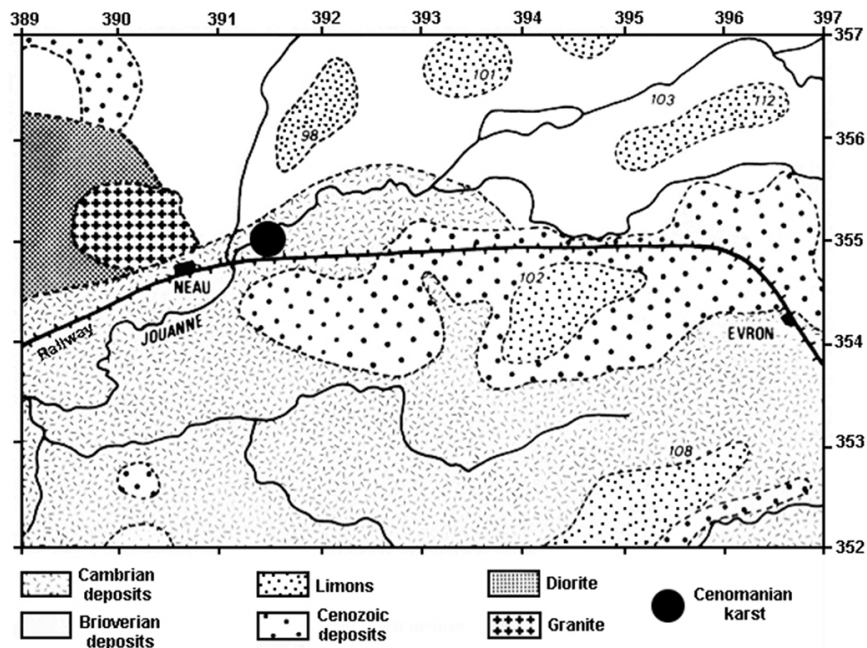

Fig. 1. Simplified geological map of the Neau area, in the Mayenne department, with location of the studied quarry.

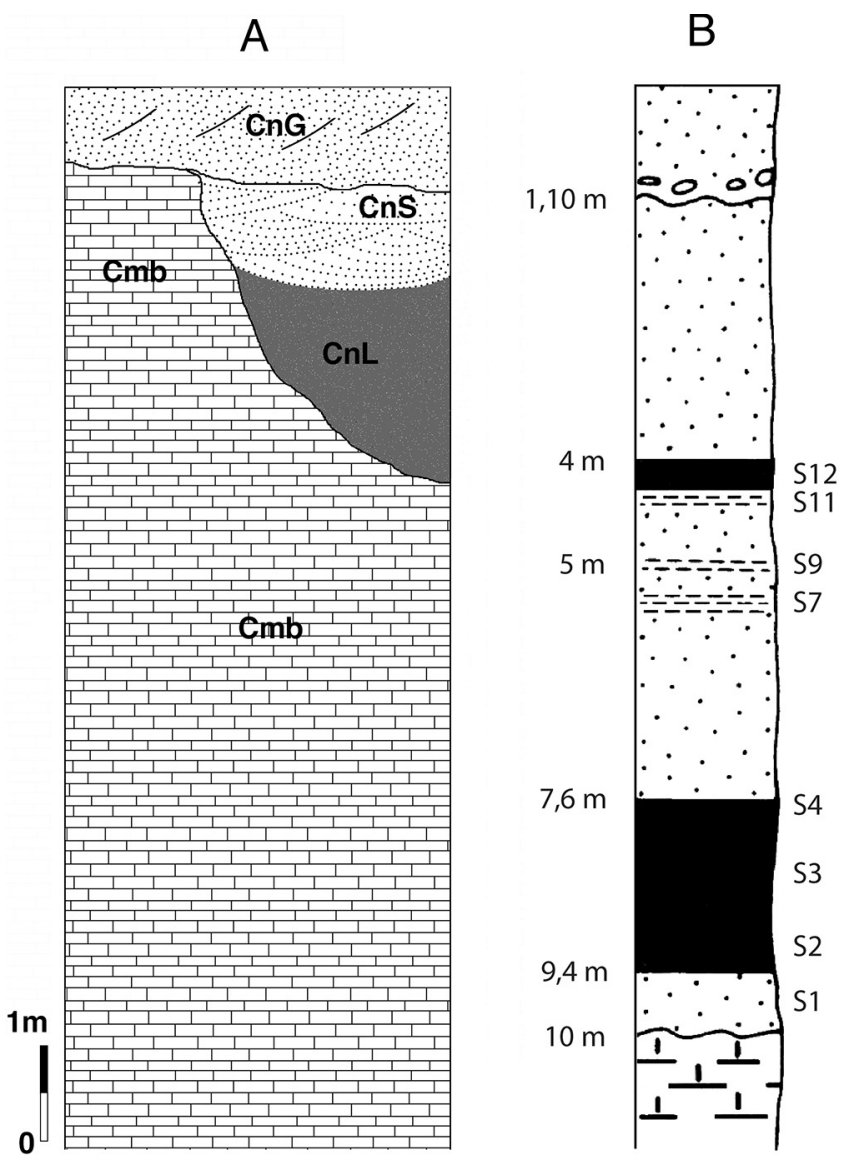

Fig. 2. Geological sections of the Cenomanian karsts from the Neau quarry. A. Synthetic section of the karsts with lignite and amber, observed by the authors $(\mathrm{Cmb}=$ Cambrian limestones; $\mathrm{CnL}=\mathrm{Cen}$ omanian lignites; $\mathrm{CnS}=$ Cenomanian sand; $\mathrm{CnG}=$ Cenomanian Glauconitic facies). B. Geological section published by Azema et al. (1972), with location of their palynological samples S1 to S12. 
slides prepared and analyzed by Azema et al. (1972) were reexamined to complete our palynological analyses and to compare our biostratigraphical and palaeobotanical conclusions (samples S2, S3, S4, S7, S9, S11, S12 on Fig. 2B).

The amber can be collected by sieving of the lignites, but can also be sometimes collected on the outcrop surface after washout by the rain. The lignites and amber studied in this paper were collected during a field trip organized on June 4th 2014 by the Museum of Laval (J. Tréguier) and the University of Rennes I (D. Néraudeau), completed by additional collections made by John Brunet and D. Gendry.

\subsection{Amber, wood and cuticle preparation (Fig. 4)}

Tiny amber grains have been collected by sieving of the lignitic clay, and then separated from wood and cuticle fragments (Fig. 4A). The lignitic marl was soaked in a solution of hydrogen peroxide $(12 \%)$ and water for a few days. The disaggregated sediment was then washed with tap water through a column of sieves $(2.0 \mathrm{~mm}, 1.0 \mathrm{~mm}$ and $0.5 \mathrm{~mm}$ meshes). The pieces of ambers as well as fossil plants (Fig. 4B-H) were picked out by naked eye or under a stereomicroscope Leica 125. Photographs were taken with a BMS digital USB camera (5 megapixels). Specimens are housed in the collections of the University of Rennes 1 under numbers IGR-PAL-2828 and IGR-PAL-22829 for the wood fragments and IGR-PAL-2830 to IGR-PAL-2836 and IGRPAL-2844/IGR-PAL-2845 for the plant cuticles. An amber lot is housed under number IGR-PAL-2843. Amber slides used to illustrate the amber inclusions correspond to numbers IGRPAL-2837 to IGR-PAL-2842. The amber grain containing wood fragments studied in the paper corresponds to number IGR-PAL-2846.

In the lignitic clay, plant remains are greatly disarticulated and vary in size including meso- to macro-remains (Fig. 4BH). They consist of leafy axes (Fig. 4B-E) and cone scales of conifers (Fig. 4F) as well as fragmented leaves of ginkgophytes (Fig. 4G, H). Wood fragments are also abundant (Fig. 4A). The collection includes hundreds of plant specimens. They are preserved as coalified compressions with or without cuticles. Some plant microremains (pollen, woods) were also found as inclusions inside amber.

In order to characterize the amber grains, thin sections were prepared with a thickness slightly greater than the standard thickness of the petrographic thin section. The optical microscope used is a Zeiss Axioscope 40 with photographing device and observations were made with $\times 5$ and $\times 10$ objectives for large observation. The observations under confocal laser scanning microscope (CLSM) were essentially performed on a Leica TCS SP5 microscope. The images obtained allow viewing of the autofluorescent objects in false colours. 3D reconstruction was obtained by acquisition of stacks of closely spaced confocal optical sections at $0.10 \mu \mathrm{m}$ to $0.20 \mu \mathrm{m}$ intervals. Then these images were treated for optimization with the open source software Image J (Rasband, 1997-2013). Amber and wood examinations with Scanning Electron Microscope (SEM) were performed with the Hitachi SU3500 model.

In addition to the micro-fragments of wood found by sieving of the lignitic clay (Fig. 4A), several large pieces of

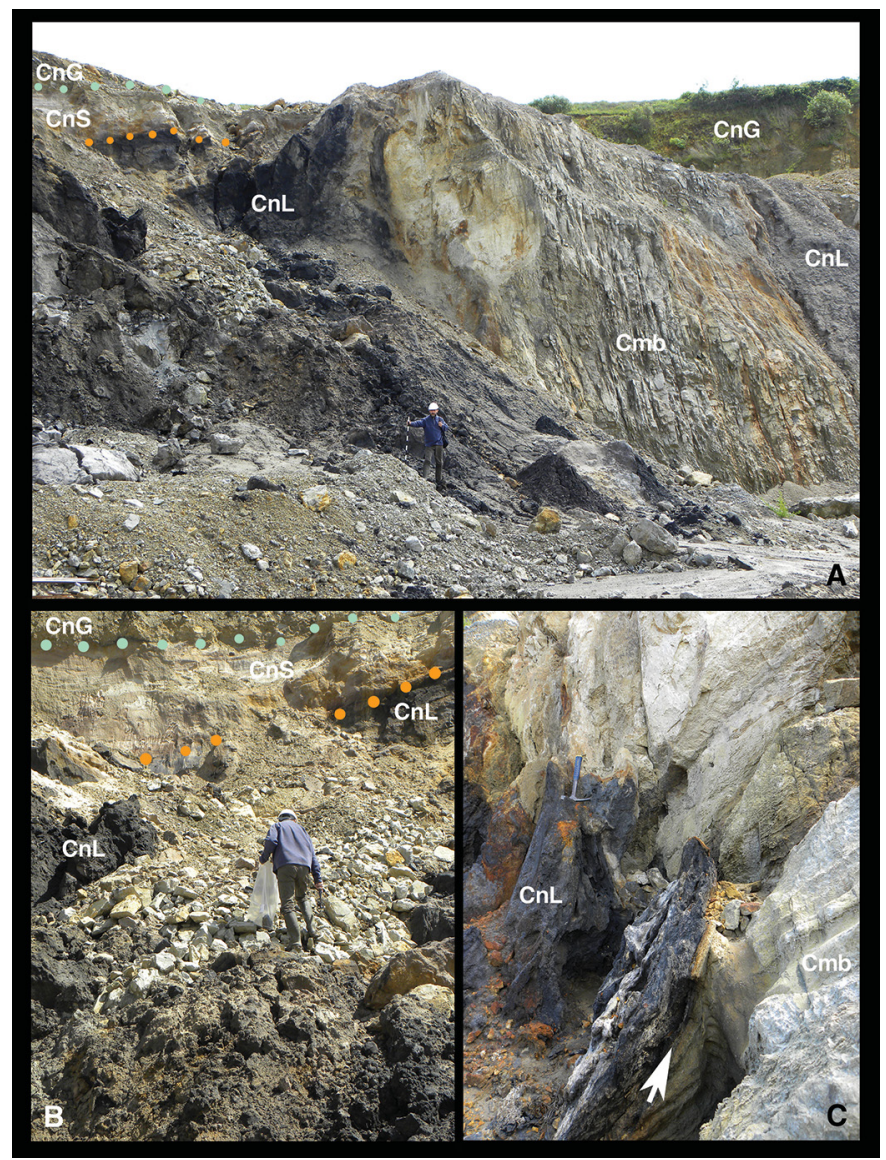

Fig. 3. Lignite and amber deposits from the Neau quarry. A. General view showing the Cenomanian lignites $(\mathrm{CnL})$ in karsts incising the Cambrian limestones $(\mathrm{Cmb})$; at the top of the quarry, Cenomanian glauconitic sands overlap both Cenomanian white sands $(\mathrm{CnS})$ and Cambrian limestones. B. One Cenomanian karst showing at its top the contact between the lignites containing amber $(\mathrm{CnL})$ and the glauconitic sands $(\mathrm{CnG})$; the bag of the collector contains a large piece of fossil wood. C. Lateral view of a Cenomanian karst with the lignites $(\mathrm{CnL})$ directly in erosive contact with the Cambrian limestones $(\mathrm{Cmb})$ (photographs D. Néraudeau).

trunk and branches have been collected during the field trip at the surface of the outcrop (Fig. 3B).

\subsection{Amber analyses}

Two pieces of Neau amber, an opaque and milky denoted form $\mathrm{A}$ and a translucent and orange denoted form $\mathrm{B}$ and a yellowish Baltic amber as reference were analyzed by thermally assisted hydrolysis and methylation (THM) also called thermochemolysis. Small portions of amber were crushed manually in an agate mortar. The powders $(\sim 0.1 \mathrm{mg})$ were heated with TMAH (Tetramethylammonium Hydroxyde) at $400^{\circ} \mathrm{C}$. THM was carried out using a Frontier Lab PY2020iD pyrolyser coupled with a Shimadzu GCMS-QP2010 Plus system operating with a split ratio of 100 . Separation was achieved using a capillary column SLB-5MS $(60 \mathrm{~m} \times 0.25 \mathrm{~mm}$ ID, $0.25 \mu \mathrm{m}$ film thickness) with the carrier gas He with a flow of $1.1 \mathrm{~mL} / \mathrm{min}$. The operating conditions were as follows: 


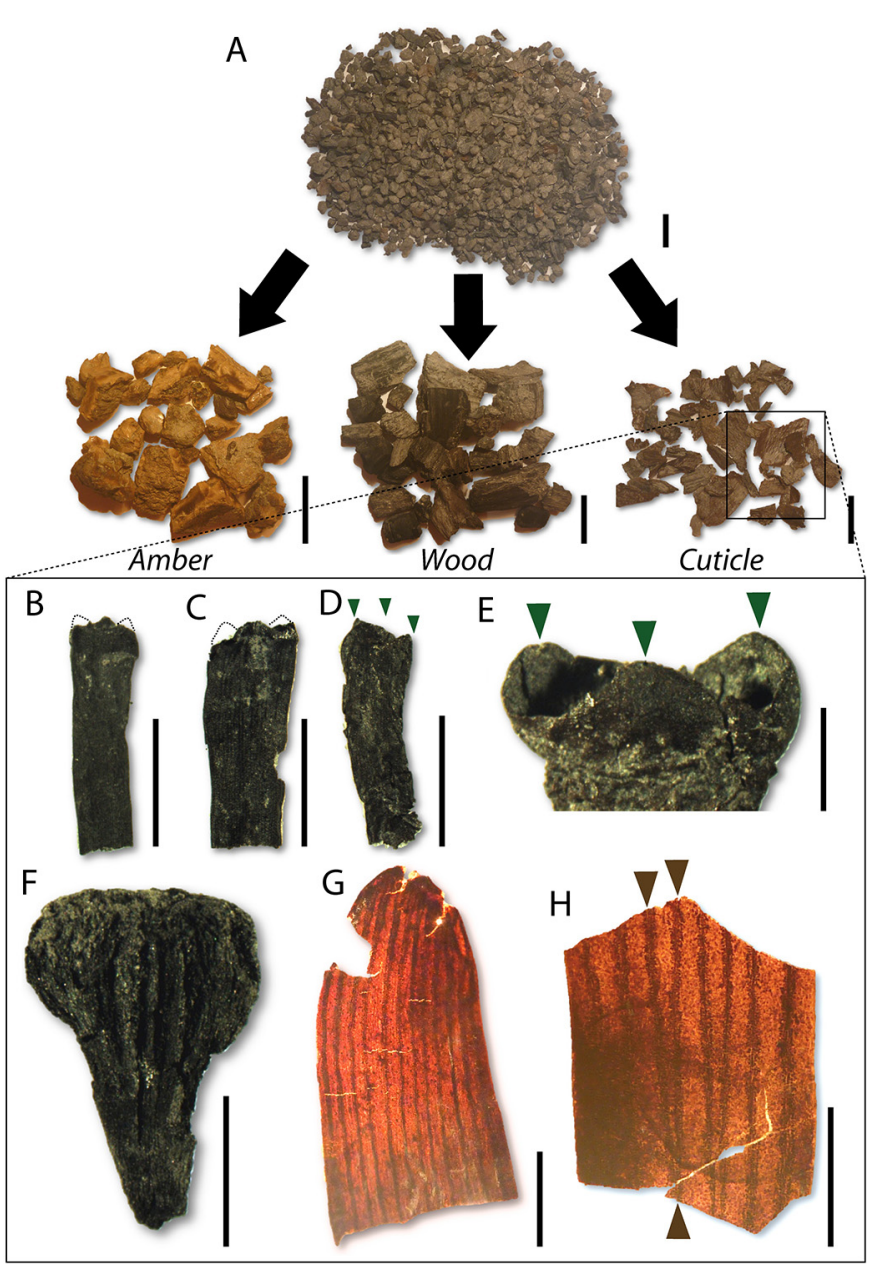

Fig. 4. A. Amber, cuticle and wood remains extracted after soaking of sediment in a solution of hydrogen peroxide. B-E. Leafy axes of the conifer Frenelopsis sp. showing the characteristic tree short parts of the leaves (located by arrows), IGR-PAL-2830 to IGR-PAL-2833. F. Conifer cone scale IGR-PAL-2834. G-H. Fragments of leaves ascribed to Eretmophyllum obtusum showing the characteristic bifid veins (located by arrows), IGR-PAL-2835 and IGR-PAL-2836. Scale bars: $\mathrm{A}=1 \mathrm{~cm} ; \mathrm{B}-\mathrm{D}$ and $\mathrm{G}-\mathrm{H}=5 \mathrm{~mm} ; \mathrm{E}=1 \mathrm{~mm} ; \mathrm{F}=2 \mathrm{~mm}$.

initial temperature held at $50{ }^{\circ} \mathrm{C}$ for 2 minutes, increased to $310^{\circ} \mathrm{C}$ at a rate of $4{ }^{\circ} \mathrm{C} / \mathrm{min}$ for 34 minutes. Individual compounds were identified based on comparison of (i) MS data with the NIST2014 library and literature (Anderson, 1994, 1996, 2006; Dutta et al., 2011; Otto and Simoneit, 2002) and (ii) retention time with the reference Baltic amber.

The relative distribution of identified compounds was determined by measuring the area of a specific fragment, denoted $\mathrm{m} / \mathrm{z}$ integration in Table 1 . The peak area of the selected $\mathrm{m} / \mathrm{z}$ for each compound was integrated and corrected by a mass spectra factor (Tab. 1) calculated as the reciprocal of the proportion of the fragment used for the integration and the entire fragmentogram. The molecular ratios were calculated using those corrected areas that allow an approximation of areas on the total ion chromatogram while preventing from the integration of co-eluting compounds.

\subsection{Palynomorphs}

Seven samples were recovered from Neau amber-rich lignitic clay in 1972, and 39 corresponding palynological slides were prepared and analyzed by Azema et al. (1972; S2, S3, S4, S7, S9, S11, S12, see Fig. 2B). Because their study focused on several Cenomanian localities of western France, Azema et al. (1972) chose not to discuss extensively the palaeoenvironmental implications and the age attribution of the palynological assemblages of Neau. The palynomorphs illustrated are not accompanied by coordinates, and one cannot know which pollen grain or spore comes from Neau or from another locality. Thus, in order to determine more precisely the palaeoenvironmental and stratigraphic modalities associated with the formation/deposit of Neau resin - and later amber -, those 39 slides were reexamined, and the corresponding results are presented herein.

Several slides now correspond to partly dried residue, rendering observations difficult, but all seven samples yielded palynological assemblages, however often small. If the sample and corresponding slides were not particularly rich, all palynomorphs were counted and identified, as it is the case for $\mathrm{S} 2(\mathrm{~N}=132), \mathrm{S} 7(\mathrm{~N}=27), \mathrm{S} 9(\mathrm{~N}=23), \mathrm{S} 11(\mathrm{~N}=135)$, and $\mathrm{S} 12(\mathrm{~N}=106)$. The two remaining samples $\mathrm{S} 3$ and $\mathrm{S} 4$ provided rich assemblages. Three hundred palynomorphs were counted and identified, but all the palynomorphs were observed in order to log potential infrequent forms (Appendix S1). The 39 slides are housed in the collections of the University of Rennes 1 under numbers $\mathrm{Cd} 1$ to $\mathrm{Cd} 39$.

\section{Plant remains from the lignitic clay}

\subsection{Coalified compressions and cuticles from the lignitic clay}

\section{Conifers}

Family Cheirolepidiaceae

Genus Frenelopsis Schenk, 1869 emend. J. Watson,1976

Frenelopsis sp.

(Fig. 4B-E)

Material. Forty-three specimens, from which IGR-PAL2830 to IGR-PAL-2833 are figured.

Description. The material consists of isolated internodes constituting the leafy axes (Fig. 4B-D). The internodes are never connected. They are elongated, flattened, up to $13.0 \mathrm{~mm}$ long, and up to $3.5 \mathrm{~mm}$ wide. Each internode is formed by one whorl of three proximally fused leaves. Free parts of the leaves are only visible distally (Fig. 4B-E). They form three tiny tips which are triangular in shape, broader than long, up to $1.0 \mathrm{~mm}$ long, and up to $2.5 \mathrm{~mm}$ wide and show an obtuse apex (Fig. 4E). Surface of internodes shows numerous longitudinal rows of stomata.

Remarks. Cellular characters of the stomata are not preserved. Frenelopsis is one of the most abundant conifers from the Cenomanian deposits of Western France. This taxon was reported from many areas in Aude, Charente-Maritime, Vienne and Maine-et-Loire (see synthesis in Moreau et al., 2017 and references therein).

\section{Family Incertae sedis}

Cone scale Type 1

(Fig. 4F) 
Table 1. List of identified compounds and their relative proportions in Neau ambers. Target compounds were identified based on $\mathrm{m} / \mathrm{z}$ int and $\mathrm{m} / \mathrm{z}$ identification. Areas were integrated using the $\mathrm{m} / \mathrm{z}$ int, and the area on the total ion chromatogram was estimated using the mass spectra factor (MSF). Non-detected compounds are denoted "n.d.".

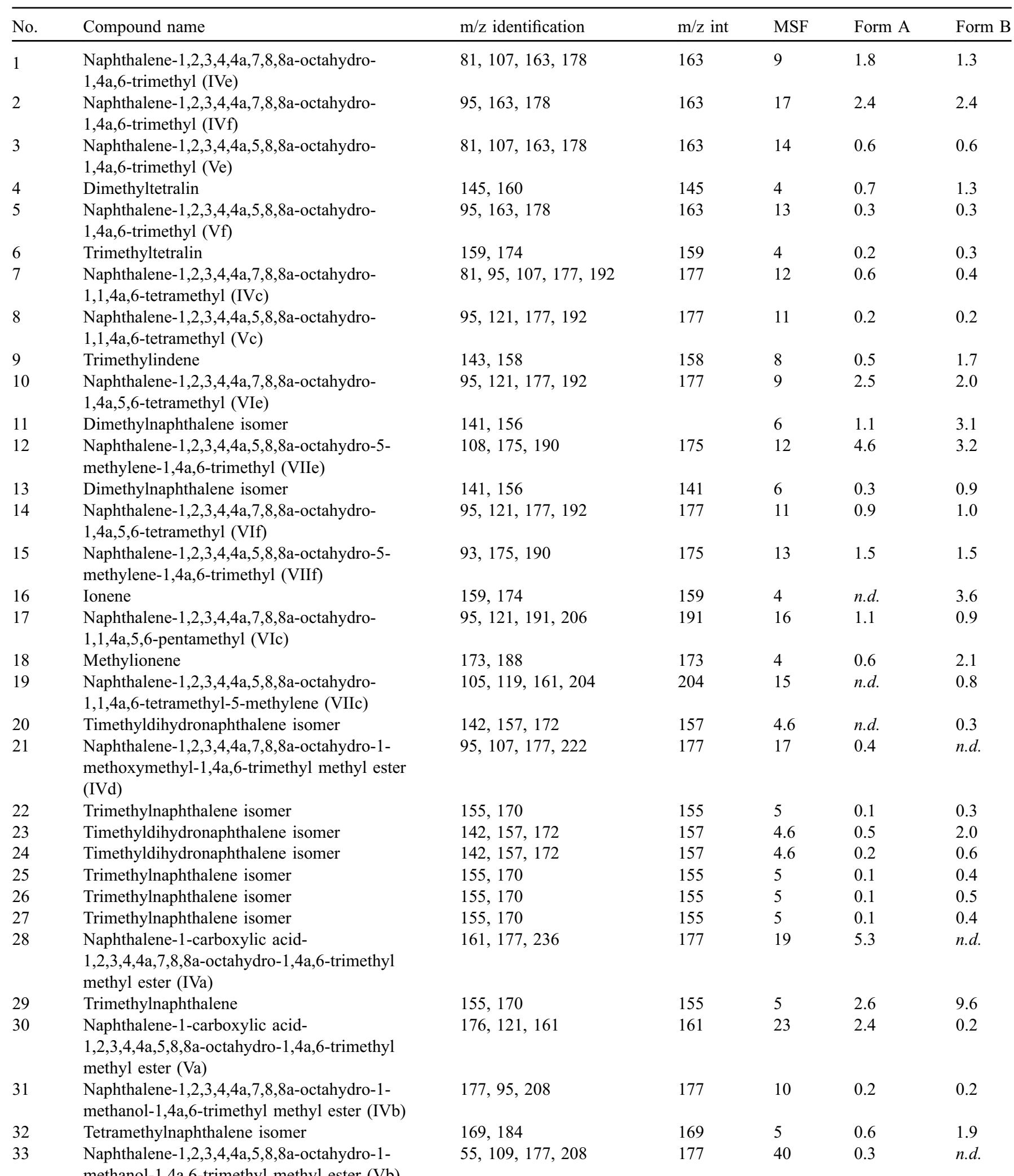


Table 1. (continued).

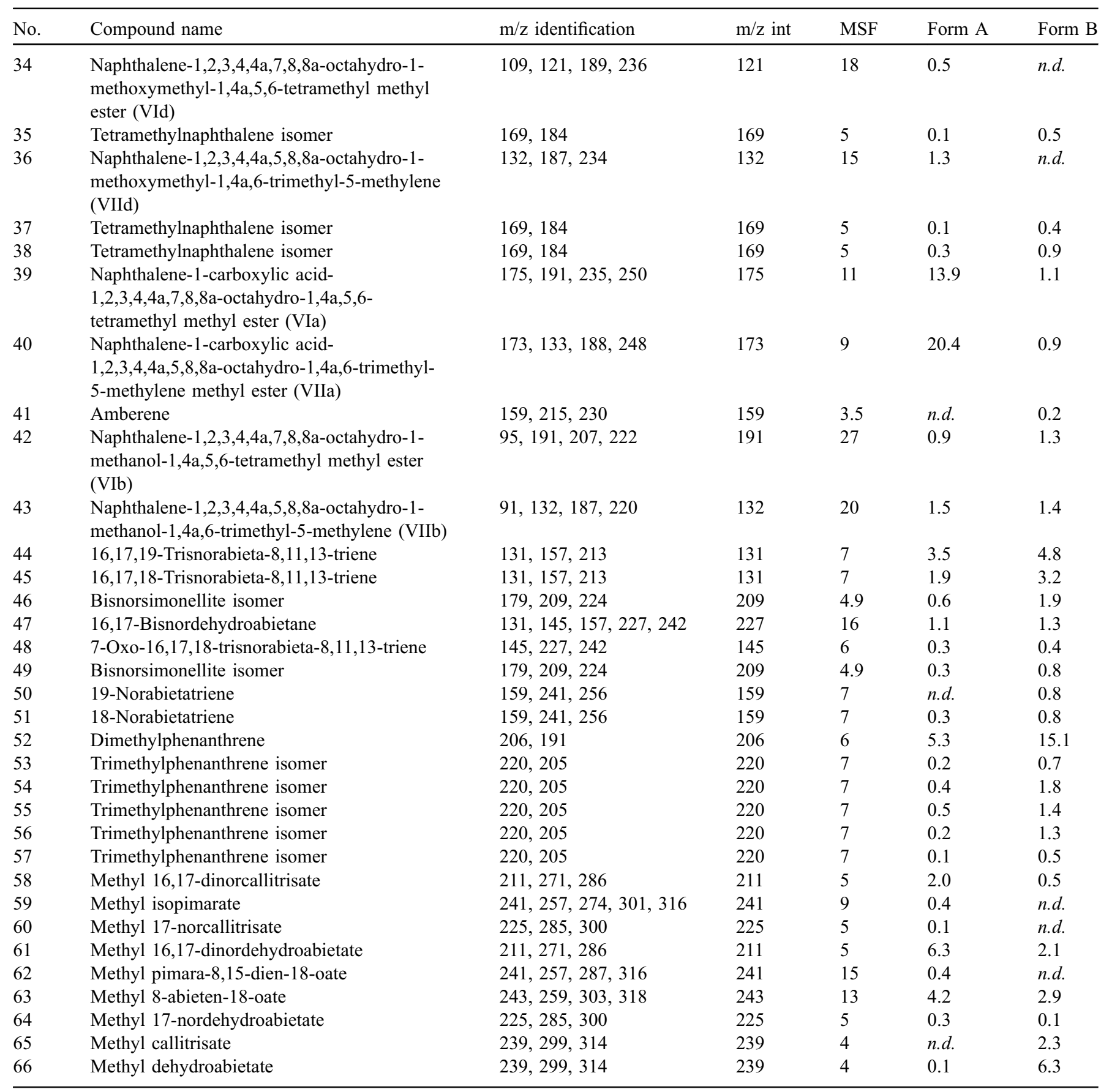

Material. One specimen, IGR-PAL-2834.

Description. The scale is longer than wide (i.e., $4.5 \mathrm{~mm}$ long and $3 \mathrm{~mm}$ wide), convex, shows an acuminate base, a broad truncate apex and an entire margin (Fig. 4F). The base displays a long free stalk ( $2.5 \mathrm{~mm}$ long and up to $1.5 \mathrm{~mm}$ wide). The adaxial surface displays several central and proximal grooves. They end before the truncate apex.

Remarks. The preservation is not sufficient to unambiguously identify the presence of ovule scars. Some isolated ovulate cone scales were previously reported from the lower Cenomanian of western France, in Charente-Maritime (e.g., Néraudeau et al., 2009). They were tentatively ascribed to Alvinia bohemica (Velen.) J. Kvaček. However, the shape of the cone scale from Mayenne differs from these specimens.

Ginkgoales

Family Karkeniaceae

Genus Eretmophyllum

Eretmophyllum obtusum (Velen.) J. Kvaček, (1999) 

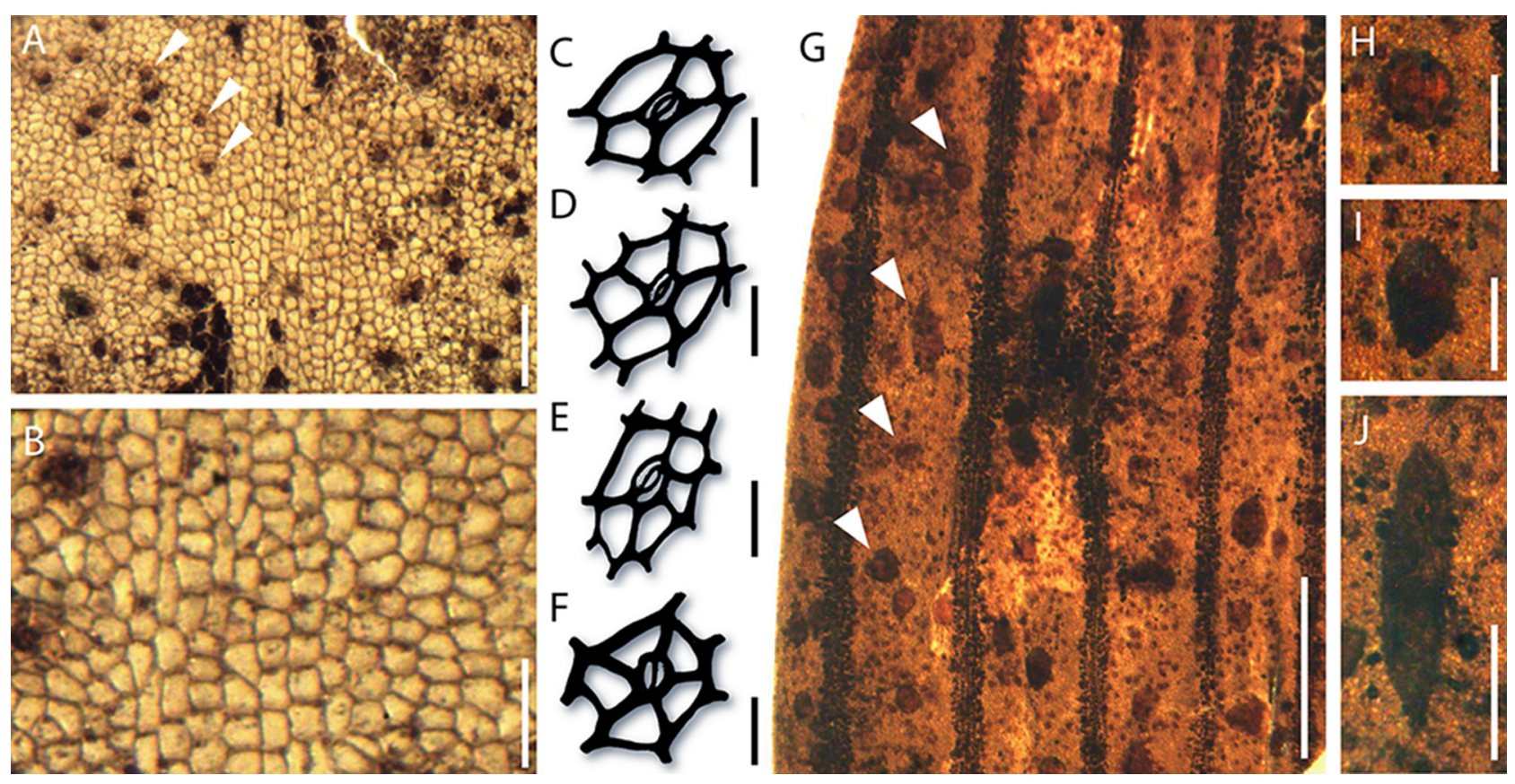

Fig. 5. Eretmophyllum obtusum. A-B. Details of cuticle showing the arrangement of cells, and the random orientation of stomatal apparatuses (white arrows), IGR-PAL-2844. C-F. Sketches of stomatal apparatuses showing arrangement of subsidiary cells. G. Arrangement of resin bodies (white arrows) preserved in the mesophyll between veins IGR-PAL-2845. H-J. Rounded and spindle-shaped resin bodies. Scale bars: A and H$\mathrm{J}=500 \mu \mathrm{m} ; \mathrm{B}=200 \mu \mathrm{m} ; \mathrm{C}-\mathrm{F}=100 \mu \mathrm{m} ; \mathrm{G}=2 \mathrm{~mm}$.

(Fig. 4G-H and Fig. 5A-J)

Material. Sixteen specimens, from which IGR-PAL-2835 and IGR-PAL-2836 are figured.

Description. The material consists of up to $20 \mathrm{~mm}$ long and up to $11 \mathrm{~mm}$ wide fragmented lamina (Fig. $4 \mathrm{G}-\mathrm{H}$ ). The leaves are coriaceous and entire-margined. The apices are obtuse. Base of leaves and petiole are not preserved. The veins are dichotomously branched and run subparallel to leaf lamina and converge near the apex (Fig. 4G-H). The dichotomies form narrow angles. In the medial part, lamina display up to 12 parallel veins. The veins are up to $0.3 \mathrm{~mm}$ wide and are regularly spaced. Cuticle is heavily cutinized. Cuticle displays costal and intercostal bands, both bearing stomata apparatuses. Leaves are amphistomatic. Stomata are randomly oriented, scattered, and particularly abundant in intercostal bands (Fig. $5 \mathrm{~A})$. Stomata are haplocheilic, sunken and surrounded by 4 to 6 subsidiary cells (Fig. 5C-F). The diameter of stomatal apparatuses varies from 40 to $70 \mu \mathrm{m}$. The stomatal pits show a round or oval shape. Ordinary epidermal cells are square, rectangular, or polygonal, $20-110 \mu \mathrm{m}$ long and form longitudinal rows. The anticlinal walls of ordinary epidermal cells are straight to slightly sinuous (Fig. 5B). Numerous rounded and spindle-shaped resin bodies are dispersed in the mesophyll (Fig. 5G). Rounded ones are up to $0.5 \mathrm{~mm}$ in diameter whereas spindle-shaped ones are up to $1.1 \mathrm{~mm}$ long (Fig. 5H-J).

Remarks. Pons et al. (1976) erected the species Eretmophyllum andegavense D.Pons, Boureau et Broutin based on material from the Cenomanian of Angers (western France). However, the distinction of Eretmophyllum (Velen.) J.Kvaček with Nehvizdya Hluštík is debated for a long time. Kvaček (1999) transfered Nehvizdya to the genus Eretmophyllum, and introduced a new combination, Eretmophyllum obtusum (Velen.) J. Kvaček. However, Gomez et al. (2000) attempted to distinguish Eretmophyllum from Nehvizdya on the basis of the presence or absence of papillae on subsidiary cells as the differential character. Gomez et al. (2000) tentatively transferred the species Eretmophyllum andegavense in the genus Nehvizdya. However, as pointed by Kvaček et al. (2005) the differential character used by Gomez et al. (2000) is not acceptable being variable among genera in the Ginkgoales. Here, we follow Kvaček et al. (2005) who suggested that Nehvizdya and Eretmophyllum cannot be splitted only based on the "papillae" argument. Although several studies (Gomez et al., 2004, 2008; Néraudeau et al., 2005) reported Nehvizdya andegavense from the Albian-Cenomanian of several localities in Charente-Maritime, we agree with Fleury et al. (2017) who used Eretmophyllum rather than Nehvizdya for material from the Cenomanian of western France (Maine et Loire).

\subsection{Palynomorphs from the lignitic clay}

The seven palynological samples yielded a fairly diverse palynoflora composed of 71 species and ca. 1000 specimens (Appendix S1). Abundance charts of the five richest samples show that the proportion between spores (Fig. 6C-L) and pollen grains (Fig. 6M-Z) is well balanced, but spores are often slightly dominant (Fig. 6A). They usually represent around $60 \%$ of the assemblage, but can go up to $92 \%$ for S4. Most abundant spores correspond to Gleicheniidites senonicus 
(Gleicheniaceae), to smooth walled forms associated with the genera Cyathidites and Deltoidospora, and to massive cicatricose spores of Appendicisporites and Cicatricosisporites (Anemiaceae; Fig. 6A, E-J). Appendicisporites insignis (Fig. 6I-J) is the most common form of ornamented spores. Among subsidiary spores are those of the Lycophytes, mostly belonging to Camarozonosporites (Fig. 6D), a few bryophitic forms (Fig. 6C), spores associated with the Osmundaceae, such as Baculatisporites (Fig. 6K), and spores of uncertain botanical affinities, like Patellasporites tavaredensis (Fig. 6L) and Microreticulatisporites sacalii.

Gymnosperm pollen grains (Fig. 6M-O) are dominated by Circumpolles (Classopollis torosus) and small inaperturate or monoaperturate grains associated with the Cupressaceae (incl. Taxodiaceae), including Exesipollenites tumulus, Inaperturopollenites dubius, and Taxodiaceaepollenites hiatus (Fig. 6A). On the contrary, bisaccates (mostly Pinaceae/ Podocarpaceae, Fig. 6M) and grains of Araucariaceae (Araucariacites, Fig. 6N) were rarely encountered, and seldom represent more than $5 \%$ of the assemblages, except for the youngest assemblage (Fig. 6A).

While the different groups of spores and gymnosperms pollen grains display a fairly fluctuant abundance throughout the five assemblages, S11 and S12 are marked by the sudden increase of angiosperm pollen grains (Fig. 6A). They represent from $3-5 \%$ of S2-S4 to $12-15 \%$ of S11-S12. Numerous representatives of Dichastopollenites were observed (uncertain affinity), as well as tricolpate (Tricolpites, Fig. 6V), tricolporate (Nyssapollenites, Fig. 6U), and tricolpoidate (Phimopollenites, Fig. 6X-Z) forms belonging to the Eudicots. Grains of Phimopollenites were particularly diversified and abundant. Less common forms include Stellatopllis cf. largissimus (Fig. 6S) and Artiopollis indivisus (Fig. 6T). No normapolles were observed. Very few dinocysts were logged in the oldest assemblages, mostly belonging to Surculosphaeridium longifurcatum (Fig. 6B). Except for the progessive increase of the abundance of the angiosperm pollen grains, and the curious abundance peak of Glecheiniidites in S4, no particular trend is noticed from S2 to S12, and the resulting interpretation will therefore consider the "Neau palynoflora" as a whole.

\section{Amber characteristics}

\subsection{General aspect (Figs. 7 and 8 )}

The collected amber grains are of variable appearance and size. Large pieces of amber are very uncommon and have been collected at the surface of the outcrop. They range from 1 to $3 \mathrm{~cm}$ in size. Three varieties of colour have been observed: milky brown (Fig. 7A), translucent honey (Fig. 7B) and opaque cork colour (Fig. 7C-D). A few ones are empty (Fig. 7D). The size of tiny amber grains collected by clay sieving varies generally from a few millimetres to one centimetre (Fig. 8A). Then, the appearance of the grains depends on the shape of the original resin drops or their posterior fragmentation, during transport or the conditions of deposit and sampling. Thus, the best preserved grains correspond to fine, more or less cylindrical flows or rather spherical drops with an attachment point. Others result from a more complex flow and show several protuberances. If some grains appear translucent with a dominant orange-yellow colour, very many grains are wholly or partly opaque with earthy or cork colours of beige to brown (Figs. 4A and 8A). The opacity is very irregularly distributed according to the grains appearance (Fig. 8B-E) corresponding to several phenomena: presence of bubbles and/or emulsions more or less coarse, colonization by filamentous microorganisms (Fig. $8 \mathrm{H}$ ) or a conjugation of both (Fig. 8B, I). The external appearance revealed by the SEM observations shows that cracks are often present on the surface of the amber grains (Fig. $8 \mathrm{~F})$. In some cases the superposition of resin flows is clearly visible (Fig. 8G).

\subsection{Plant microremains included inside amber}

\subsubsection{Vegetal fibers and wood (Fig. 9)}

The size of the large pieces of wood collected on the outcrop varies from several centimetres to about $1 \mathrm{~m}$, and numerous ones show Teredo-borings typical for coastal marine environments in transgressive settings (Gingras et al., 2004), and tiny borings of unknown origin (Teredo, insect attacks?) (Fig. 9A, B). SEM observations of the wood fragments included in the amber evidenced pitting on the radial tracheid walls, preserved as pit chamber inner casts (Fig. 9C, D). While some up to 9 pits long row of contiguous pits occurred (Fig. 9D), locally pit rows seems to be interrupted (Fig. 9C). The regularity of the spacing between the preserved pits, however, argues more for non-preservation than for absence of pits. Consequently the tracheid radial pitting was interpreted as araucarian. The cross-fields are of the araucarioid type, with 5 to 7 contiguous alternate cupressoid oculipores (Fig. 9E). The fragmentary material did not allow to study growth-ring features, nor the occurrence or resin canals or axial parenchyma. According to these limited morphological observations, the most probable taxa are (from the most probable to the least one) (1) Agathoxylon; (2) Brachyoxylon; (3) Ginkgoxylon. The fact that these wood pieces are included in the amber could indicate that the resin producers were Araucariacae or Cheirolepidiaceae. These are indeed the only wood genera yet reported from the Mesozoic and combining araucarioid cross-fields and at least partly araucarian radial tracheid pitting (Philippe and Bamford, 2008).

All these three genera are known to produce resin inside their tracheids (Philippe, 1995), and the three of them were reported from the Cenomanian of Western France (Perrichot, 2005). The first and xylologically most probable one, Agathoxylon, was reported associated to all ambers with the same provenance. Despite its etymology genus Agathoxylon is not necessarily a univocal evidence of the Araucariaceae. After this has been suspected several times, it has recently been shown that Agathoxylon wood can also occur in Cheirolepidiaceae (Steart et al., submitted). Brachyoxylon is usually considered as related to the Cheirolepidiaceae (Macchour and Pons, 1995) and Ginkgoxylon to the Ginkgoalean (Jiang et al., 2016). Here in Neau, according to the non-woody remains all the three taxa occur (i.e. Araucariaceae, Cheirolepidiaceae and Ginkgoalean). The amber-embedded fragment of wood therefore does not make it possible to specify the taxonomic origin of this amber. 
A
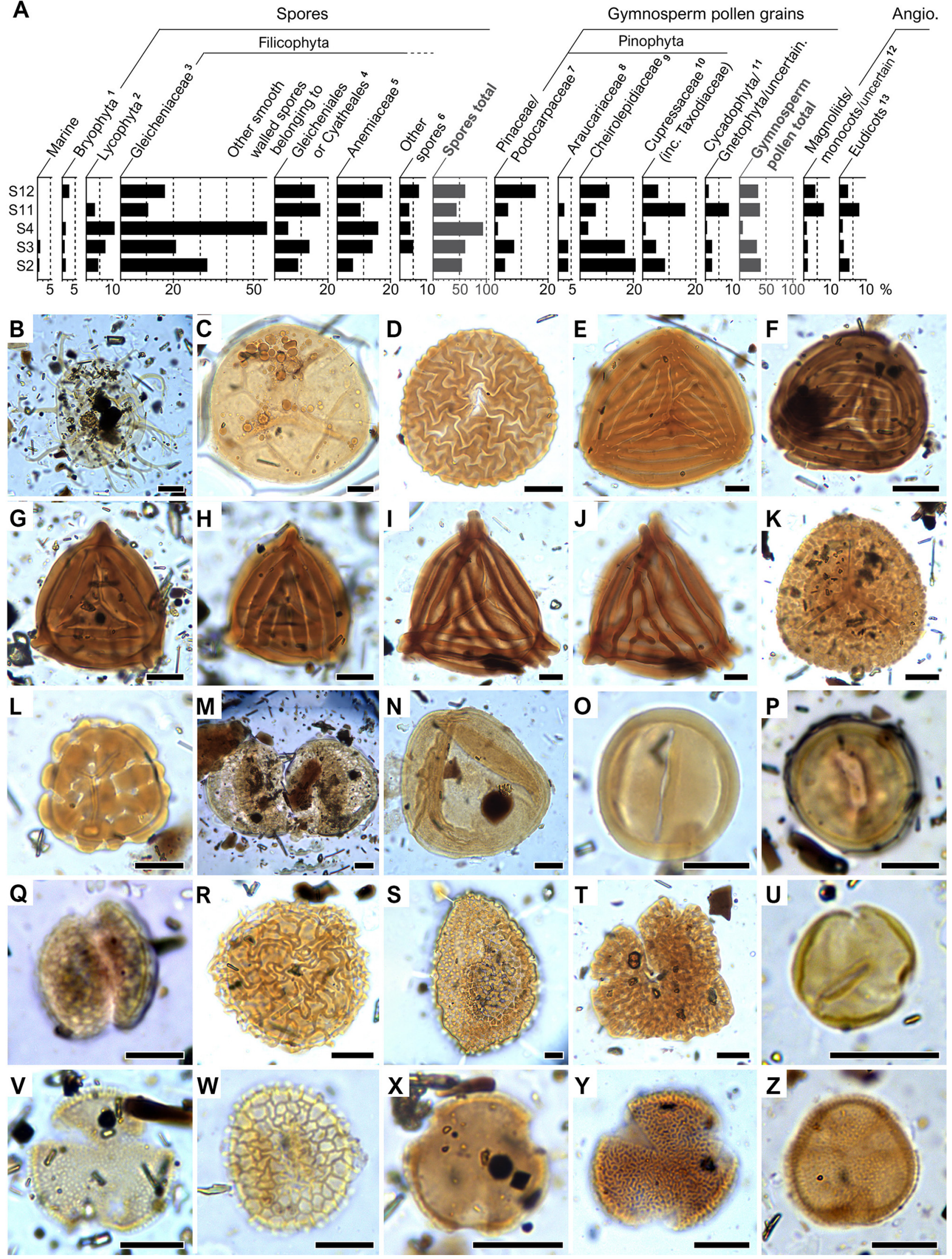


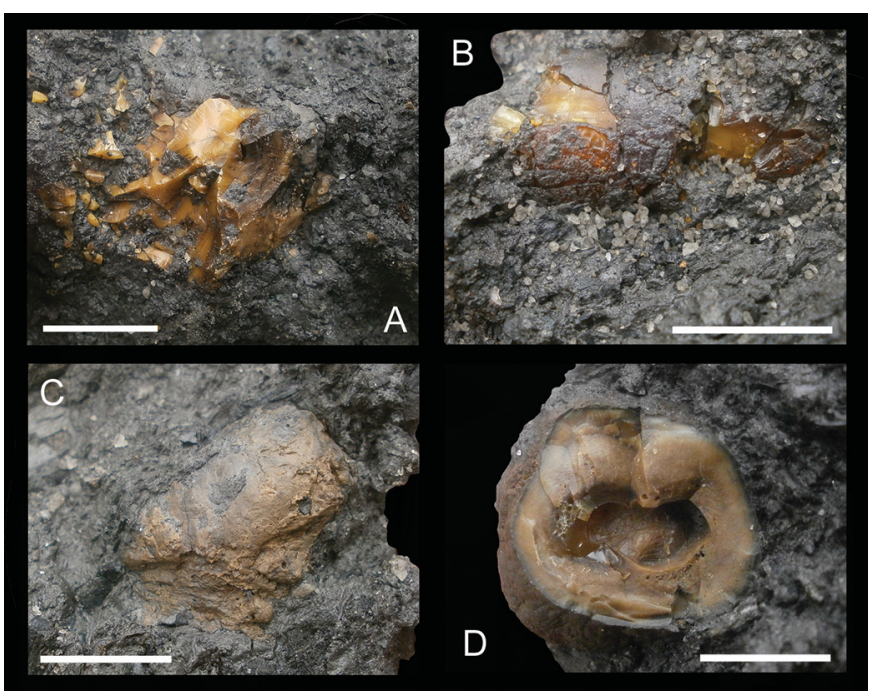

Fig. 7. Large amber pieces from the Neau quarry. A. Milky brown variety. B. Translucent honey variety. C. Cork colour variety. D. Empty piece of cork colour variety; note the black colouring of the peripheral part, linked to the proliferation of the sheated bacteria Leptotrichites resinatus. Scale bar $=10 \mathrm{~mm}$.

\subsubsection{Pollen grains included in amber (Fig. 10)}

Examination of some thin sections revealed the presence of gymnosperm pollen grains belonging to the genus Classopollis, which is associated with the extinct family of the Cheirolepidiaceae (Balme, 1995; Schrank, 2010; Fig. 10). They are often arranged in clusters (Fig. 10A-B, F), but isolated grains were also observed (Fig. 10C-D). Their rimula is discrete, but discernable. Azema et al. (1972) found numerous Classopollis grains within the lignitic clay of Neau, that they all identified as a new species called Classopollis tenuiparietalis. However, they state that $C$. tenuiparietalis is morphologically identical to the Aptian and Cenomanian Portuguese taxon Classopollis obidosensis Groot and Groot,
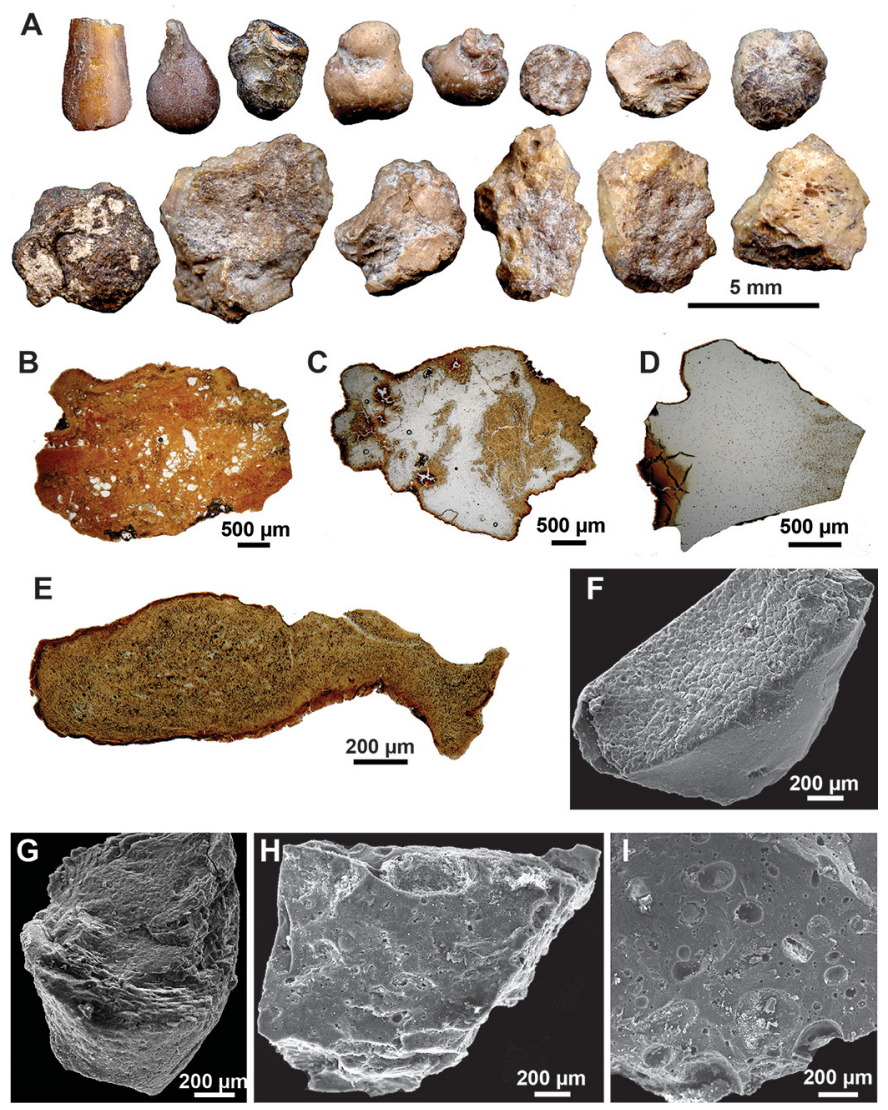

Fig. 8. Amber features. A. Forms and aspects of the collected amber grains, some having kept the characteristics of the original resin drops; note the abundance of opaque grains with earthy colours. B-E. Sections of grains in thin sections showing various situations of more or less opaque grains. F. Cracked external surface of a grain under SEM. G. Stack of resin flows within a grain. H. Opaque grains marked by dense filamentous networks. I. Opaque grain containing many bubbles and colonization by filamentous networks.

Fig. 6. A. Abundance charts of the most productive palynological assemblages from the amber-rich lignitic clays of Neau. Charts are based on the botanical affinities of the various spores and pollen morphotypes. Encountered genera: 1: Aequitriradites, Stereisporites, Triporoletes; 2: Camarozonosporites, Densoisporites, Retitriletes; 3: Gleicheniidites, Ornamentifera; 4: Cyathidites, Deltoidospora, Dictyophyllidites, Matonisporites, Toroisporis; 5: Appendicisporites, Cicatricosisporites, Distaltriangulisporites; 6: Auritulinasporites, Baculatisporites, Concavissimisporites, Laevigatosporites, Microreticulatisporites, Patellasporites, Todisporites; 7: Parvisaccites, Piceaepollenites, Podocarpidites, Pristinuspollenites; 8: Araucariacites, Balmeiopsis, Callialasporites; 9: Classopollis; 10: Exesipollenites, Inaperturopollenites, Perinopollenites, Taxodiaceaepollenites; 11: Alisporites, Afropollis, Cycadopites, Eucommiidites, Monosulcites; 12: Clavatipollenites, Dichastopollenites, Pennipollis, Retimonocolpites, Stellatopollis, Transitoripollis; 13: Artiopollis, Nyssapollenites, Phimopollenites, Retitrescolpites, Tricolpites. Species list, counts and references are available on Appendix S1. B-Z. Dinocysts, spores and pollen grains recovered from Neau lignitic clays. Accompanying data are palynological preparation and England Finder coordinates. Scale bars represent $10 \mu \mathrm{m}$. B. Surculosphaeridium longifurcatum (Firtion) Davey et al., S3-Cd9, N30.4. C. Triporoletes cenomanianus (Agasie) Srivastava, S11Cd28, R45.4. D. Camarozonosporites insignis Norris, S4-Cd16, J31.4. E. Cicatricosisporites cf. mohrioides Delcourt and Sprumont, S11-Cd31, P36.0. F. Cicatricosisporites annulatus Archangelsky and Gamerro, S3-Cd9, F29.2. G, H. Appendicisporites bilateralis Singh, S3-Cd7, K41.0. I, J. Appendicisporites insignis (Markova) Chlonova, S4-Cd11, J46.1. K. Baculatisporites sp., S3-Cd8, R48.1. L. Patellasporites tavaredensis Groot and Groot, S11-Cd28, J42.0. M. Podocarpidites biformis Rouse, S3-Cd6, M32.3. N. Araucariacites australis Cookson ex Cooper, S11Cd31, L47.1. O. Eucommiidites minor Groot and Penny, S11-Cd29, P45.0. P. Transitoripollis anulisulcatus Góczán and Juhász, S3-Cd6, M31.0. Q. Dichastopollenites reticulatus May, S4-Cd14, S46.4. R. Dichastopollenites sp. 4 sensu Heimhofer et al., (2007), S11-Cd29, B40.0. S. Stellatopollis cf. largissimus Singh, S4-Cd16, K48.0. T. Artiopollis indivisus Agasie, S4-Cd16, K52.1. U. Nyssapollenites albertensis Singh, S3Cd8, R48.3. V. Tricolpites cf. vulgaris (Pierce) Srivastava, S3-Cd7, H48.4. W. Tricolpites aff. virgeus (Groot, Penny and Groot) Hasenboehler, S11-Cd28, F35.0. X. Phimopollenites tectatus Singh, S3-Cd7, K47.1. Y. Phimopollenites megistus Singh, S4-Cd16, M33.1. Z. Phimopollenites cf. pannosus (Dettmann and Playford) Dettmann, S11-Cd33, L37.4. 


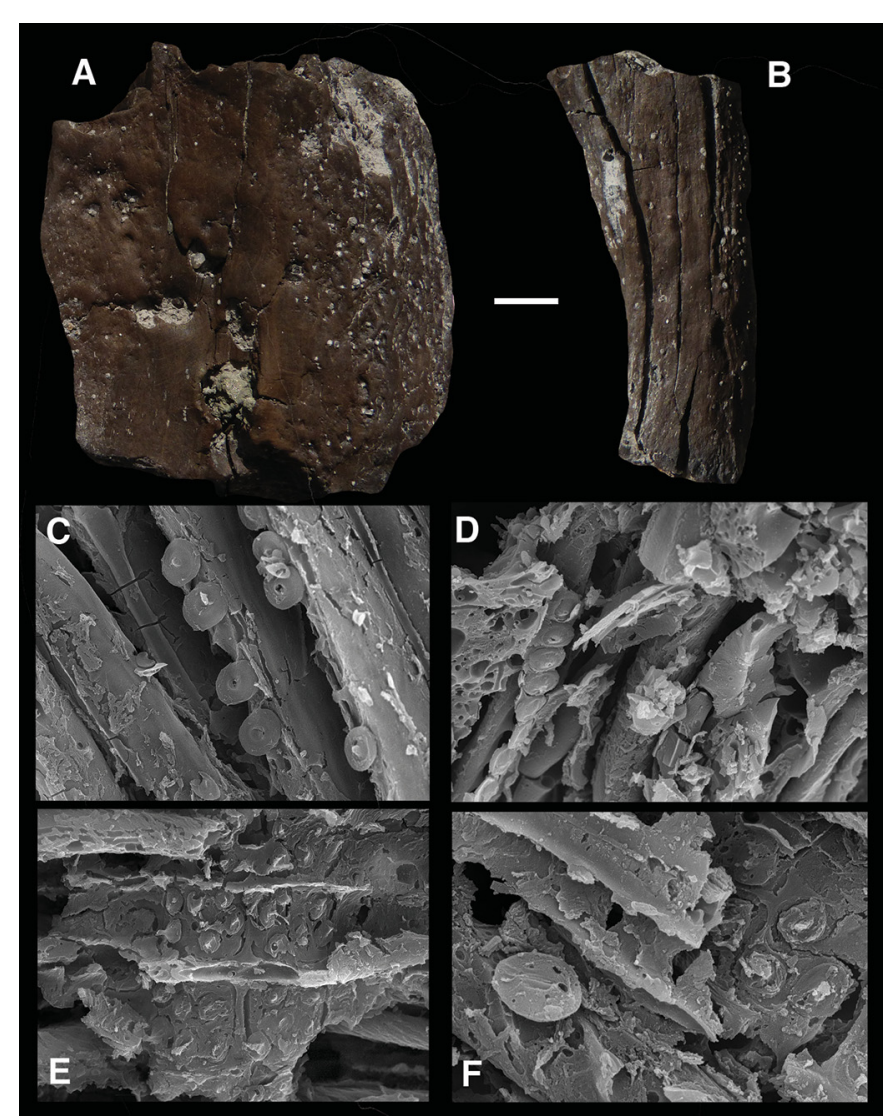

Fig. 9. Optical (A-B) and SEM (C-F) photographs of wood fragments. A. Large piece of fossil wood showing large Teredo borings on the left and numerous tiny borings (insect attacks?) on the right, IGR-PAL-2828. B. Piece of branch showing tiny borings IGRPAL-2829. C. Areolated pit inner casts; note that tori left a circular depression in the centre of the casts (magnification $\times 1700$ ). D. Araucarian row of uniseriate contiguous radial pits (magnification $\times 1300$ ). E. Five araucarioid cross-fields, with poorly preserved contiguous alternate cupressoid oculipores (magnification $\times 1600$ ). $\mathrm{F}$. An isolated areolated pit (foreground) and an araucarioid cross-field (background) (magnification $\times 3500$ ). SEM observations have been made on specimen IGR-PAL-2846. Scale bar for A and B: $10 \mathrm{~mm}$.

creating this new form only to accommodate Cenomanian French pollen grains. Classopollis tenuiparietalis is thus considered invalid. As the morphological differences between C. obidosensis, C. classoides Pflug, and C. torosus (Reissinger), Couper are very tenuous, we consider them all synonymous of the first form described, Classopollis torosus (see diagnoses of Couper, 1958, pp. 156-157, and Groot and Groot, 1962, p. 161). This latter species is then adopted for the pollen grains from Neau amber.

Trapped palynomorphs have been mostly recovered from Eocene Baltic amber (Wetzel, 1953; Arnold, 1998; see Langenheim and Bartlett, 1971 for 1800s and early 1900s references). A few other studies on subsidiary Cenozoic amber bearing strata have also documented spores and pollen grains in Eocene amber from France (Breton et al., 1999; De Franceschi et al., 2000; Dejax et al., 2001), and Miocene amber from Peru and Mexico (Langenheim in Poinar, 1992, p. 78; Antoine et al., 2006). Mesozoic records are scarce, and

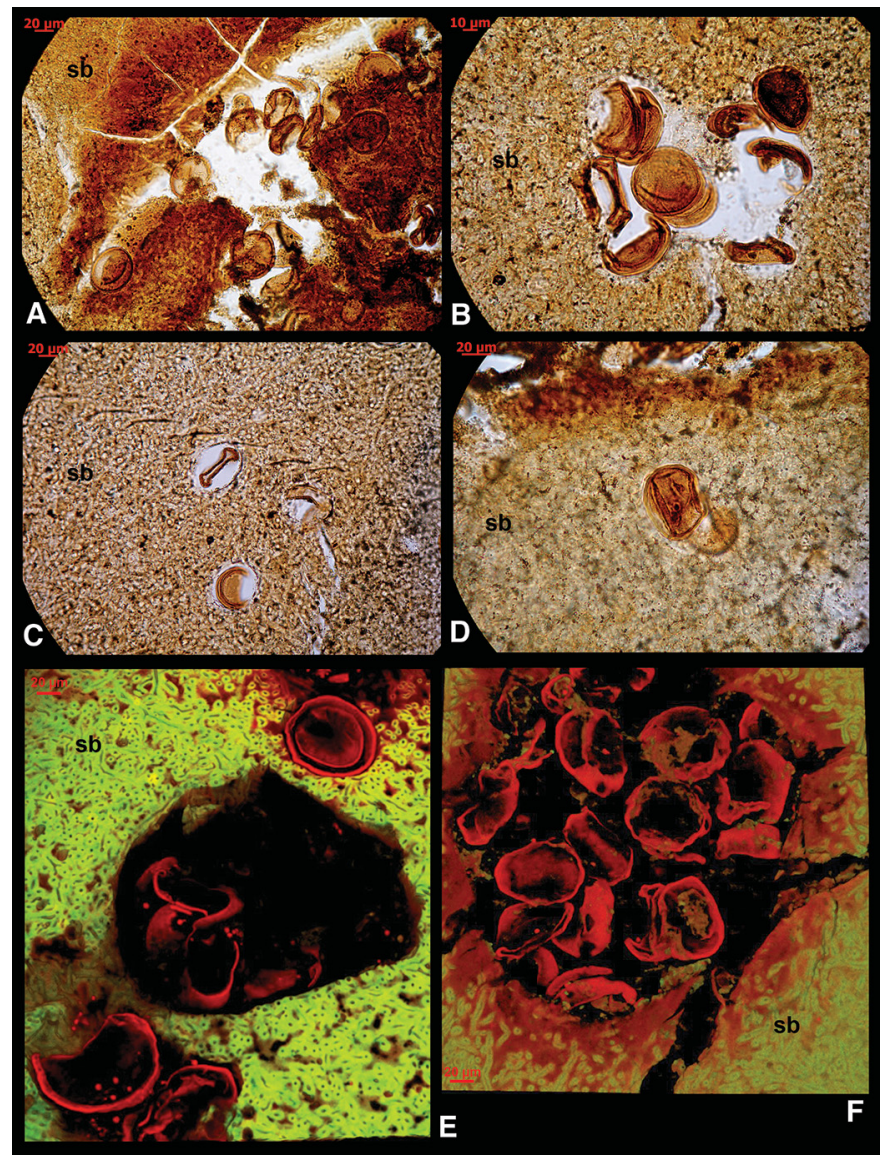

Fig. 10. Palynomorphs inclusions in amber. A-F. Inclusions of Classopollis pollen grains in the Cenomanian amber of Neau (Mayenne). Generally pollen grains are grouped in vacuoles of the amber and can be numerous (A, B, E, F), IGR-PAL-2837 to IGRPAL-2840. Only a few ones are isolated in the fossil resin (C, D), IGR-PAL-2841 and IGR-PAL-2842. Note the dense filamentous network due to the colonization of the resin by a sheathed bacterium (sb). A-D. Optical microscope. E-F. Confocal microscope (CLSM).

concerns exclusively Cretaceous strata. Angiospermous pollen grains and spores were apparently recovered from Lower Cretaceous Lebanese amber, but neither precise reference nor illustrations are provided (Azar et al., 2010; Engel et al., 2011; Whalley in Poinar, 1992, p. 161). Several clusters of gymnosperm and angiosperm pollen grains were recovered from the Cenomanian Myanmar amber, always observed in association with various insects (Poinar, 2010; Cai et al., 2018; Grimaldi et al., 2019; Lin et al., 2019; Hinkelman and Vršanská, 2020). In Europe, Monsulcites grains were observed within late Albian amber from Spain (Peris et al., 2017). The Classopollis clusters described herein are the first pollen grains documented from Mezosoic French amber so far.

\subsubsection{Microinclusions}

The amber of Neau contains various inclusions of microorganisms (Saint Martin et al., under study) characterized by centripetal colonization of filamentous networks. They are essentially sheathed bacteria identifiable as Leptotrichites resinatus Schmidt 2005 whose colonization density in the 

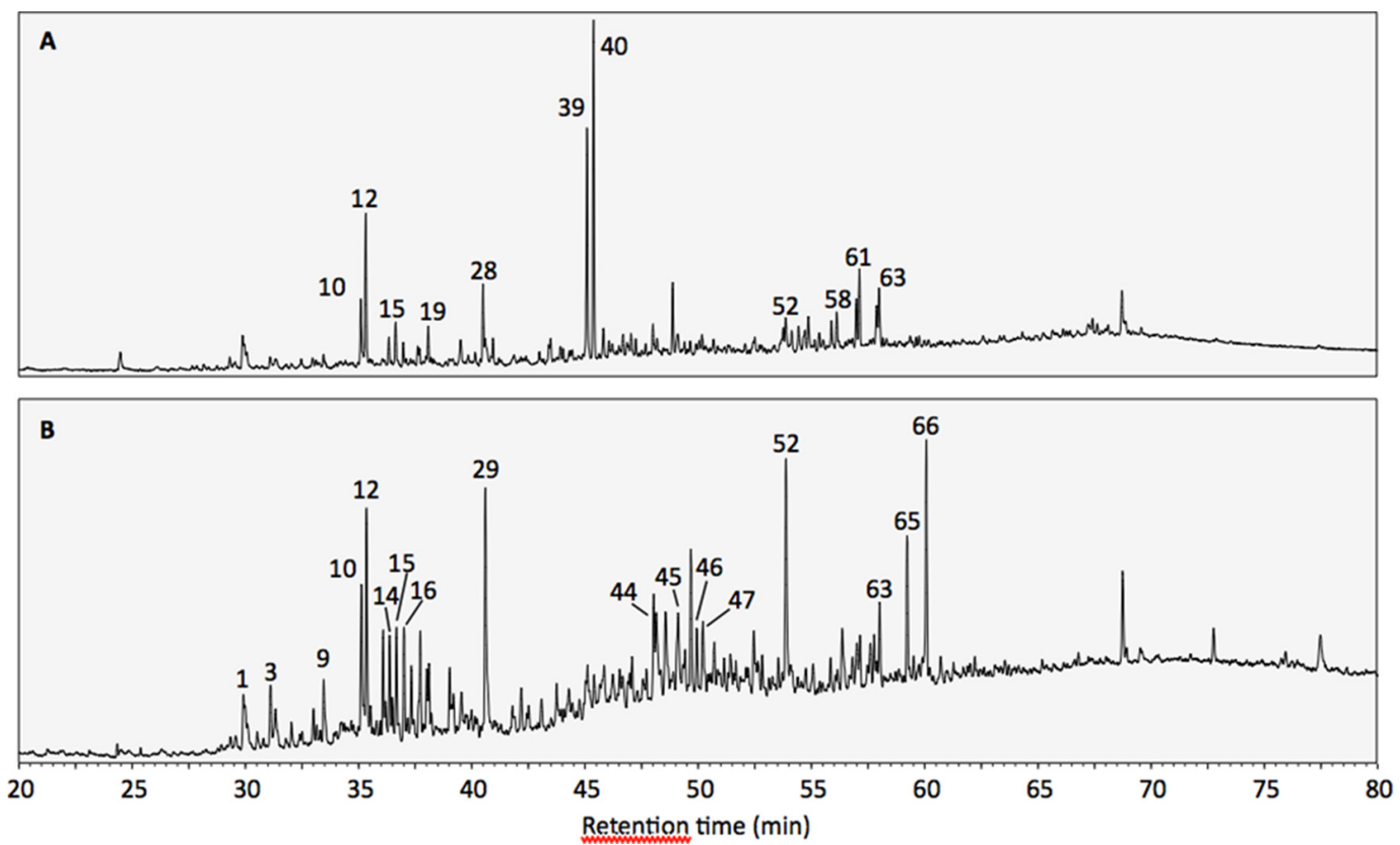

Fig. 11. Total ion chromatogram from the THM-GC-MS analysis of Neau amber form A (A) and form B (B). Numbered peaks refer to identified compounds in Table 1 and Appendix S2.

Table 2. Relative proportions of the three categories of identified compounds and of labdanoid diterpenes. Compositional ratio calculated on the distribution of labdanoid diterpenes.

\begin{tabular}{lcl}
\hline & Form A & Form B \\
\hline $\begin{array}{l}\text { Relative proportions of identified compounds } \\
\text { Labdanoid diterpenes }\end{array}$ & 64 & \\
$\begin{array}{l}\text { Methyl(hydro)naphthalene } \\
\text { and methylphenanthrene }\end{array}$ & 21 & 20 \\
Tricyclic diterpenes & 15 & 64 \\
Relative proportions of labdanoid diterpenes & 16 \\
Carboxylic acid & 66 & \\
Alcohol & 8 & 11 \\
1-Dimethyl & 3 & 15 \\
1-Methyl & 23 & 12 \\
Compositional ratios $\Sigma C 14 / \Sigma C 15$ & & 62 \\
Carboxylic acid & 0.23 & \\
Alcohol & 0.22 & 0.11 \\
1-Dimethyl & 0.77 & 0.09 \\
1-Methyl & 0.71 & 0.34 \\
All labdanoid diterpenes & 0.24 & 0.88 \\
\hline
\end{tabular}

${ }^{\mathrm{a}}$ Including amberene.

initial resin results of the complete opacification of the amber grains (Figs. 7C, D, 8E, I, 10A-F), and often of black colouring of the peripheral parts of the amber drops, just below the crust surface (Fig. 7D). These microinclusions are very widespread in Cretaceous ambers (Schmidt and Schäfer, 2005; Saint Martin and Saint Martin, 2018). Smaller clumps of actinomycetes are also found to a lesser extent, located on the periphery of the amber grains.

\subsubsection{Chemical characteristics}

The total ion chromatograms of the THM-GC-MS analysis of the Neau resins are illustrated in Figure 11. The relative proportions of (i) the different categories of compounds and (ii) labdanoid diterpenes and compositional ratios are given in Table 2. The molecular fingerprint was composed of 66 molecules from three main families: (i) labdanoid diterpenes produced by the thermochemolysis of the A/B ring system of a polylabdanoid structure, (ii) methyl(hydro)naphthalene and methylphenanthrene and (iii) tricyclic diterpenes. Both pieces of ambers produced a different chemical fingerprint. Most of the compounds $(80 \%)$ occurred in both fingerprints, but in different relative proportions.

Labdanoid diterpenes are the main chemical group in form A (64\% of the analyzed compounds), while they only represent $20 \%$ of the analyzed compounds in form B (Tab. 2). The similarity of the retention times of the carboxylic acids compared with Baltic amber and the absence of dimethyl succinate classified these samples as Class Ib ambers. Labdanoid diterpens of form $\mathrm{A}$ are dominated by bicyclic acids $(66 \%)$ with a large predominance of $\mathrm{C}_{15}$ over $\mathrm{C}_{14}\left(\Sigma \mathrm{C}_{14} /\right.$ $\left.\mathrm{SC}_{15}=0.23\right)$. In form $\mathrm{B}$, they are dominated by 1 -methylbicyclic hydrocarbons (64\% of labdanoid diterpens) with a slight predominance of $\mathrm{C}_{15}$ over $\mathrm{C}_{14}\left(\mathrm{\Sigma}_{14} / \mathrm{SC}_{15}=0.88\right)$.

Methyl(hydro)naphthalene and methylphenanthrene are the main chemical group in form B $(64 \%$ of analyzed compounds), while they represent $21 \%$ of the analyzed compounds in form A. This group included trimethylindene, ionene, methylionene and diagenetic products of sesqui- and diterpenoids. The distribution of these compounds is quite 
similar in both form with the predominance of 5 isomers of trimethylnaphthalene (38 and $36 \%$ in form $\mathrm{A}$ and $\mathrm{B}$, respectively) and 2 isomers of dimethylnaphthalene (17 and $13 \%$ in form $\mathrm{A}$ and $\mathrm{B}$, respectively). Amberene was detected in low amount in the program of form $B$ and represented $0.5 \%$ of this chemical group.

The third chemical category was composed of tricyclic diterpenes. In form A, this group was dominated by methyl 16,17-dinordehydroabietate (23\%), dimethylphenanthrene (19\%) and methyl 8-abieten-18-oate (15\%) with low occurrence of callitrisic acid derivatives. In form $\mathrm{B}$, this group was dominated by dimethylphenanthrene (32\%), methyl dehydroabietate $(13 \%)$ and the isomers of trimethylphenanthrene (12\%). Methyl callitrisate (5\% and methyl 16,17-dinorcallitrisate $(1 \%)$ were also detected.

\section{Discussion}

\subsection{Singularity of the amber from Neau}

The appearance of the Cenomanian amber of Neau is very similar to that of the amber grains generally collected in many Cretaceous French amber deposits of various ages. The same reduced size and the drop shape of the best preserved grains can be found in other Cenomanian French sites: e.g. Poitou (Valentin et al., this volume), Sarthe (Breton and Tostain, 2005; Breton, 2007; Girard et al., 2013a, 2013b). This feature is also common for the Turonian of Dordogne (Saint Martin et al., 2013a, 2013b; Néraudeau et al., 2016) and Aude (Breton et al., 2018), the Santonian of Provence (Saint Martin et al., 2012, 2013; Saint Martin and Saint Martin, 2018; Frau et al., this volume; Saint Martin et al., this volume), and the Campanian of Aude (Breton et al., 2013). On the other hand, they do not correspond to amber samples taken from the AlboCenomanian of Charente Maritime or the Upper Cretaceous from Vendée, where large nodules can be found (Néraudeau et al., 2008; Girard, 2010; Néraudeau et al., 2017).

Consequently, like in Dordogne, Poitou or Provence ambers, the very small size of the amber drops from Neau did not favour the preservation of arthropod inclusions as large amber drops from the Charentes and Vendée did. The only micro-inclusions that have been observed in the amber from Neau correspond to filamentous organisms such as sheathed bacteria and actinomycetes. But other micro-organisms, such as amoeba or diatoms seem to be lacking.

Conversely, palynological inclusions, which were never observed in French Cretaceous ambers, are well preserved in Neau amber (see Sect. 4.2.2). The lack of palynomorphs, known to be resistant to physical and chemical taphonomical processes, is difficult to explain for the other Cretaceous French ambers. Their presence in the Mayenne amber could be related to a season of resin flow more contemporaneous to the conifer pollination. Langenheim and Bartlett (1971) have noticed that the probability of finding pollen in amber can be increased when pollen was produced throughout the entire period of resin secretion. However, they also observed that several genera of palynomorphs were trapped throughout the year within resin, regardless of either time of pollination and period of resin production. As Cretaceous palynomorphs have been generally noticed when they are found in association with insects and plants (see Sect. 4.2.2), it could be possible that spores and pollen grains were trapped within other Cretaceous amber, but were not observed because they were not in the vicinity of larger fossils. However, the researches of Girard (2010), (2013, 2018) and Saint Martin et al. (2012, 2013a, $2013 \mathrm{~b}$ ) dedicated to the identification of every microinclusions in French Cretaceous ambers devoid of arthropod inclusions, have never observed pollen grains in these ambers, in spite of their diversity of geographical (centre-western, south-western or south-eastern France) and stratigraphical (Albian, Cenomanian, Turonian, Santonian, Campanian) origins. The case of Lebanese amber shows another original situation, the pollen grain species trapped in the Lower Cretaceous Hammana amber lacking in the palynological assemblage of the sediment containing the amber (Azar et al., 2010).

The chemical fingerprints of form $\mathrm{A}$ and $\mathrm{B}$ ambers composed of labdanoid diterpenes produced, methyl(hydro)naphthalene, methylphenanthrene and tricyclic diterpenes is typical of Cretaceous ambers (Anderson, 2006; Bray and Anderson, 2008; Menor-Salván et al., 2016; Nohra et al., 2015). Both chemical fingerprints shared $80 \%$ of the detected compounds and the 66 analyzed molecules fall in the three aforesaid chemical classes. Based on the higher proportion of methyl (hydro)naphthalene and methylphenanthrene (Clifford et al., 1995 ) and lower $\Sigma C 14 / \Sigma C 15$ (Clifford et al., 1999), the differences in the chemical fingerprints could be interpreted as a higher degree of maturation for form $B$ than for form A. However both come from the same deposit, so the same diagenetic conditions could be assumed. Since $80 \%$ of the molecules are common to both fingerprints, a similar botanical precursor may be assumed. In such a situation, the differences between both fingerprints could be due to the initial composition of the resin that can present large seasonal and inter-specific variations (Langenheim, 2003) and/or from heterogeneities in the physicchemical conditions of the deposit.

The chemical fingerprint of form A is characterized by (i) the predominance of labdanoid diterpenes with a predominance of bicyclic acids and (ii) the occurrence of tricyclic diterpenes coming from dehydroabietic and callitrisic acids with a predominance of dehydroabietic acid derivatives. It is similar to that described for the Cretaceous amber from the Raritan formation (Anderson, 2006) that has been assigned to the Cupressaceae. However the vegetal macrofossils from Neau are not from this family. Moreover the chemical fingerprint of the Cretaceous amber from Vendée (France) assigned to the Cupressaceae is characterized by a large predominance of callitrisic acid derivatives over dehydroabitic acid derivatives (Nohra et al., 2015).

Bisnorsimonellite also occurred in form A. The chemical fingerprint of this form $\mathrm{A}$ is similar to that described for the Charentese (France) Cretaceous amber (Nohra et al., 2015). The chemical fingerprint of the form $\mathrm{B}$ is characterized by the occurrence of traces of amberene and by a higher proportion of 16,17,18-trisnorabieta-8,11,13-triene versus 18-norabietatriene. It is similar to that described for the type 2 Cretaceous ambers from Spain (Menor-Salván et al., 2016). The extinct family Cheirolepidiaceae has been suggested as the potential producer of these ambers, which is in accordance with the vegetal macrofossils associated with the Neau ambers. Consequently Neau ambers may be assigned to the Cheirolepidiaceae. 
The present data reinforce the chemical signature suggested for the ambers produced by the extinct family Cheirolepidiaceae. The combination of previous observations (Bray and Anderson, 2008; Menor-Salván et al., 2016; Nohra et al., 2015) and the present data suggests the following chemical fingerprint: (i) occurrence of labdanoid diterpenes, (ii) occurrence of tricyclic diterpenes coming from dehydroabietic and callitrisic acids with a predominance of dehydroabietic acid derivatives, (iii) a higher proportion of 16,17,18-trisnorabieta-8,11,13-triene versus 18-norabietatriene (Tab. 2), (iv) absence or occurrence in low proportion of amberene and (v) occurrence of ferruginol or its diagenetic products such as bisnorsimonellite.

\subsection{Age of the lignitic clay(s)}

Despite the revealing title of their study, Azema et al. (1972) did not consider all the palynological assemblages they observed to be mid-Cenomanian in age. This is the case of the palynoflora recovered from Neau, which they interpreted as lower to mid Cenomanian. They based their age attribution (1) on the presence of the same species of Classopollis in the clays of both Neau and Ecommoy, the latter being unequivocally mid-Cenomanian, and (2) on the absence of the form Lobelina, which would be indicative of an Albian age (Azema et al., 1972, p. 10). However, we consider herein that the specimens identified as Classopollis belong to the long-ranging form $C$. torosus (see Sect. 3.2). Moreover, the Circumpolle genus Lobelina created by Médus (1970) was later proven to be a nomen nudum (Jansonius and Hills, 1976), and is considered as a form of Classopollis. In any case, the use of Circumpolles to date Mesozoic deposits has not been proven satisfactory in spite of Médus efforts to produce a comprehensive morphologic and stratigraphic identification key (Médus, 1970). Thus, to confirm the age attribution made by Azema et al. (1972), supplementary palynological arguments must be made.

Several observations support a Cenomanian rather than Albian age for the lignitic clays of Neau. The presence of Artiopollis indivisus (Fig. 6T) is worth being noted, this form having been observed only in Late Cretaceous palynofloras so far, especially Cenomanian (Singh, 1983; Ravn and Witzke, 1995; Lupia, 1999). The occurring of Microreticulatisporites sacalii is sometime considered as a stratigraphic argument in favour of a Cenomanian age (Peyrot et al., 2019) because it has been almost exclusively found within Cenomanian strata (Deák and Combaz, 1967; Médus and Triat, 1969; Peyrot et al., 2019), but Ravn (1995) observed this species in late Albian assemblages of Wyoming. If this form is frequently encountered, it may be considered as relatively stratigraphically significant, when coupled with other stratigraphic arguments. The observation of numerous tricolpoidate and tricolporate forms, such as Phimopollenites and Nyssapollenites, is also indicative of Cenomanian rather than Albian assemblages. Specimens belonging to those genera, and more generally tricolporate pollen grains, appear very scarcely during the Albian, but become much more frequent and diverse during the Cenomanian (Doyle and Robbins, 1977; Hochuli et al., 2006). Actually, those tricolpoidate and tricolporate specimens were encountered more frequently in the palynoflora from Neau than in the lower Cenomanian palynofloras recovered from
Charente-Maritime, Charente, and Vienne (Peyrot et al., 2019; Polette et al., 2019). The absence of indubitable midCenomanian markers, such as Normapolles, has to be acknowledged. The lack of observation does not necessarily mean that Normapolle grains were not present in Neau palynoflora, and the absence of a form cannot be considered as stratigraphically significant. However, Normapolles complex diversified quite rapidly from the end of mid Cenomanian onward (Méon et al., 2004) and several species were usually encountered from other mid to late Cenomanian assemblages from western France (Azema et al., 1972; Néraudeau et al., 2017). If they were to be found in Neau lignites, they are certainly very scarce.

The palynoflora from Neau is then probably younger than the charentese palynofloras, and older than Normapolles-rich mid Cenomanian palynofloras from Vendée (western France; Azema et al., 1972; Néraudeau et al., 2017), agreeing with the regional stratigraphic correlations of Azema et al. (1972). A possible age of upper lower Cenomanian or lower mid Cenomanian (which is virtually the same) is then attributed to the Neau amber-bearing lignitic clays.

\subsection{Palaeoenvironment}

Such poorly diversified conifer-dominated plant assemblage is common in the Laurasian littoral floras during the Albian-Cenomanian. Albian-Cenomanian floras yielding the conifer Frenelopsis as well as the ginkgophyte Eretmophyllum (or Nehvizdya) were reported from several palaeobotanical sites of western France, including the Archingeay quarry and the Renardières quarry in Charente-Maritime (Néraudeau et al., 2005), and the Brouillard quarry in Maine-et-Loire (Pons, 1979; Néraudeau et al., 2013). The abundance of both the leafy axis Frenelopsis and the dispersed pollen grain Classopollis as well as the chemical signature of the amber suggest that Cheirolepidiaceae were one of the main component of the flora bordering the palaeokarsts from Neau. Although both are isolated in the sediment from Neau, Classopollis was reported attached on microsporangiate cones of Frenelopsis alata from other Cenomanian palaeobotanical sites of Europe (e.g. Kvaček, 2000). As it was remonstrated in the Albian-Cenomanian deposits of western France (e.g. Pons, 1979; Néraudeau et al., 2005, 2013; Girard et al., 2013a, 2013b; Moreau et al., 2014, 2017) and other European localities (e.g. Kvaček, 2000), the genus Frenelopsis is related to littoral environments commonly with strong marine influence. Ecophysiologically, the xerophytic characters of the conifer Frenelopsis clearly show that the flora from Neau was adapted to withstand intense sunlight and coastal environments exposed to desiccant conditions coupled in haline settings: sheathing leaves, thick cuticle, grooved epidermal cells, epidermal hairs, stomata in sunken lines, and stomata with two levels of papillae (Thévenard et al., 2005). These morphoanatomical characteristics allow a reduction of solar radiations, drying air circulations and evapotranspiration.

Classopollis shows a wide geographical distribution. The genus has been reported in high proportions from near-coastal settings, such as sandy bars or coastal islands with welldrained soils (Alvin, 1982; Abbink, 1998), as well as in upland 
slope habitats (Filatoff, 1975; Vakhrameev and Doludenko, 1977). However, the abundance of Classopollis in the Jurassic and Cretaceous of Russia and North America shows a marked decrease northward, at higher and cooler palaeolatitudes (Pocock, 1972). When recovered with Frenelopsis remains, the presence of this genus is likely to be indicative of warm coastal habitats. The observation of numerous Classopollis clusters within the amber from Neau suggests that their parent plants grew in the vicinity of the depositional environment. The presence of very scarce Surculosphaeridium longifurcatum and foraminifera lining supports the hypothesis of an environment submitted to occasional marine inputs (Appendix S1; Fig. 6A).

The composition of the palynological assemblages of Neau is very similar to that of the Cenomanian assemblages from western France described by Peyrot et al. (2019) and Polette et al. (2019), sharing numerous common species. The present study underlines the fact that all lower to mid-Cenomanian spore assemblages from western France are dominated by Anemiaceae, Gleicheniaceae, and Cyatheales, with often numerous lycopods, mostly belonging to Camarozonosporites (see Azema et al., 1972; Peyrot et al., 2019; Polette et al., 2019). Modern Cyatheales are concentrated at the tropics but can occupy varied habitats (Kramer in Kramer and Green, 1990). Their recurring presence at Neau agrees with a globally warm mid-Cretaceous climate, already suggested by the numerous Classopollis pollen grains (Kujau et al., 2013). Representatives of the Gleicheniaceae are considered to be opportunistic, pioneering tropical to subtropical plants, adapted to long droughts, growing in unstable habitats such as dry forests and wetlands that occasionally dry out (Coiffard et al., 2007; Mehltreter et al., 2012; Kujau et al., 2013). Modern Anemiaceae usually develop under warm and humid environments, and their Mesozoic relatives may have grown along riverbanks, or as understorey in forests (Dettmann and Clifford, 1991; Van Konijnenburg-Van Cittert, 2002). However, some species of Anemiaceae are adapted to more arid conditions, and may tolerate partial desiccation (Proctor and Tuba, 2002; Schrank, 2010). No suggestion has been previously made about the ecological requirements of the potential parent plant of Camarozonosporites, which has been associated with Lycopodiaceae (Ravn, 1995; Schrank, 2010). Extant forms usually develop in fairly sheltered, dark and humid environments, such as conifer forests understorey. They also can grow along riverbanks and streams, or as epiphytes on mossy tree trunks (Rusea et al., 2009). A few species, such as Lycopodiella cernua, are even adapted to more arid condition, and can develop in open and sunny areas (Rusea et al., 2009). While some representatives of Gleicheniaceae, Anemiaceae, and Lycopodiaceae correspond to drought-resistant plants, the majority of extant ferns flourishes in wet conditions, and a high spore content is generally used as indicator of humid settings. Subordinate elements of the palynoflora, such as Todisporites, or diversified Eudicots pollen assemblage support the hypothesis of the existence of a partly riparian hygrophilous plant community (Abbink et al., 2004; Peyrot et al., 2019). Other minor forms recovered from Neau palynoflora, such as Densoisporites and Alisporites, have been interpreted as indicators of tidaly influenced environments (Abbink et al., 2004). The recurring presence of several species of cupressaceous inaperturate pollen grains herein, including Inaperturopollenites dubius, Taxodiaceaepollenites hiatus, Perinopollenites halonatus, along with araucariaceous related forms (Appendix S1) could also suggest also the existence of conifer forests linked to wet lowlands, such as in low salinity back-swamp environments, based on the ecological requirement of some modern Cupressaceae (Schrank, 2010; Peyrot et al., 2019; Appendix S1).

Peyrot et al. (2019) and Polette et al. (2019) discussed extensively the hypothetical environmental settings corresponding to Cenomanian palynofloras from western France, and described various riparian to coastal plant communities which developed under humid and warm condition. They are associated with palynological assemblages grading from (1) assemblages clearly dominated by Classopollis which would indicate downstream and coastal environments associated with xeric communities (cheirolepids, some representatives of drought-tolerant Gleicheniaceae and Anemiaceae) to (2) assemblages dominated by diversified spores, bisaccates and angiosperm pollen grains which would represent more upstream depositional environments associated with riparian hygrophilous plant communities. The composition of the palaeobotanical and palynological assemblages from Neau is intermediate. The corresponding depositional environment was subjected to a very limited connection to the sea, while associated with both drought-resistant plants and hygrophilous ferns and angiosperms. It could well have corresponded to the upstream portion of a mangrove or the most inner part of a lagoon. Depositional settings associated with mangrovetype environments has now been abundantly suggested to accommodate lower to mid- Cenomanian plant communities of western Europe (Batten, 1974; Gomez et al., 2008; Peyrot et al., 2019; Polette et al., 2019). The abrupt increase of the abundance of angiosperm pollen grains is interpreted as a reflection of the group's radiation.

\section{Supplementary Material}

Appendix S1. Species list of palynomorphs recovered from the productive lower mid-Cenomanian clay deposits of Neau, along with potential botanical affinities and counts per sample. Appendix S2. Molecules identified in the pyrolysates of Neau ambers. Individual compounds are labelled according to the identification of peaks in Table 1 .

The Supplementary Material is available at https://www.bsgf. $\mathrm{fr} / / 10.1051 / \mathrm{bsgf} / 2020039 / \mathrm{olm}$.

Acknowledgements. The authors are greatly indebted to the Society Chaux \& Dolomie Françaises/Lhoist France Ouest for the authorization to access to the outcrop. They thank Paul Bessin and Valentin Prugneaux for their participation to the field trip. The preparation of thin sections was performed by Severin Morel (UMR 7207). We thank also Géraldine Toutirais (PTME, Muséum National d'Histoire Naturelle, Paris) for his assistance with scanning electron microscopy. The CLSM investigations were performed at the Institute of Biology Paris-Seine Imaging Facility that is strongly supported by the "Conseil Regional Île-de France", the French National Research Council (CNRS) and Sorbonne University. 


\section{References}

Abbink OA. 1998. Palynological investigations in the Jurassic of the North Sea region. In: LPP Contribution Series 8. Utrecht: University of Utrecht, $192 \mathrm{p}$.

Abbink OA, Van Konijnenburg-Van Cittert JHA, Visscher H. 2004. A sporomorph ecogroup model for the Northwest European JurassicLower Cretaceous: concept and framework. Netherlands Journal of Geosciences 83: 17-38.

Aimin F, Xiaohan L, Weiming W, Xiaoli L, Liangjun Y, Feixin H. 2005. Preliminary study on the spore-pollen assemblages found in the Cenozoic sedimentary rocks in Grove Mountains, east Antarctica and its climatic implications. Chinese Journal of Polar Sciences 16: 23-32.

Alvin KL. 1982. Cheirolepidiaceae: biology, structure and paleoecology. Review of Palaeobotany and Palynology 37: 71-98.

Anderson KB. 1994. The nature and fate of natural resins in the geosphere-IV. Middle and Upper Cretaceous amber from the Taimyr Peninsula, Siberia-evidence for a new form of polylabdanoid of resinite and revision of the classification of Class I resinites. Organic Geochemistry 21(2): 209-212. https:// doi.org/10.1016/0146-6380(94)90155-4.

Anderson KB. 1996. New evidence concerning the structure, composition, and maturation of class I (Polylabdanoid) resinites. In: Amber, Resinite, and Fossil Resins. American Chemical Society 617: 105-129.

Anderson KB. 2006. The nature and fate of natural resins in the geosphere. XII. Investigation of C-ring aromatic diterpenoids in Raritan amber by pyrolysis-GC-matrix isolation FTIR-MS. Geochemical Transactions 7(2). https://doi.org/10.1186/ 1467-4866-7-2.

Antoine P-O, De Franceschi D, Flynn JJ, Nel A, Baby P, Benammi M, et al. 2006. Amber from western Amazonia reveals Neotropical diversity during the middle Miocene. Proceedings of the National Academy of Sciences 103: 13595-13600.

Archangelsky S, Archangelsky A. 2005. Aequitriradites Delcourt \& Sprumont y Couperisporites Pocock, esporas de hepaticas, en el Cretacico Temprano de Paragonia, Argentina. Revista del Museo Argentino de Ciencias Naturales 7: 119-138.

Arnold V. 1998. Vergessene Einschlüsse-Blütenstaub in baltischem Bernstein. Mitteilungen aus dem Geologisch-Paläontologischen Institut. Univ. Hamburg 81: 269-282.

Azar D, Gèze R, Acra F. 2010. Lebanese amber. In: Penney D, ed. Biodiversity of fossils in amber from the major world deposits. Manchester (UK): Siri Scientific Press, pp. 271-298.

Azema C, Durand S, Medus J. 1972. Des miospores du Cénomanien moyen. Paléobiologie continentale, Montpellier, France 3: 1-54.

Balme BE. 1995. Fossil in situ spores and pollen grains: an annotated catalogue. Review of Palaeobotany and Palynology 87: 81-323.

Batten DJ. 1974. Wealden palaeoecology from the distribution of plant fossils. Proceedings of the Geologists' Association 85: 433-457.

Batten DJ, Dutta RJ. 1997. Ultrastructure of exine of gymnospermous pollen grains from Jurassic and basal Cretaceous deposits in Northwest Europe and implications for botanical relationships. Review of Palaeobotany and Palynology 99: 25-54.

Bray PS, Anderson KB. 2008. The nature and fate of natural resins in the geosphere XIII: a probable pinaceous resin from the early Cretaceous (Barremian), Isle of Wight. Geochemical Transactions 9(3). https://doi.org/10.1186/1467-4866-9-3.

Breton G. 2007. La bioaccumulation de microorganismes dans l'ambre : analyse comparée d'un ambre cénomanien et d'un ambre sparnacien, et de leurs tapis algaires et bactériens. Comptes Rendus Palevol 6: 125-133.
Breton G, Gauthier C, Vizcaïno D. 1999. Land and freshwater microflora in a Sparnacian amber from the Corbières (South France): first observations. Estudios del Museo de Ciencias Naturales de Álava 14: 161-166.

Breton G, Bilote M, Eychenne G. 2013. L'ambre campanien du Mas d'Azil (Ariège, France) : gisement, microinclusions, taphonomie. Annales de paléontologie 99: 317-337.

Breton G, Champion S, Bilotte M. 2018. L'ambre turonien du ruisseau des Tarquès (Commune de Duilhac-sous-Peyrepertuse, Aude, France). Bulletin de la Société d'Histoire Naturelle de Toulouse 154: 161-176.

Breton G, Tostain F. 2005. Les microorganismes de l'ambre cénomanien d'Ecommoy (Sarthe, France). Comptes Rendus Palevol 4: 31-46.

Cai C, Escolana HE, Li L, Yin Z, Huang D, Engel MS. 2018. Beetle Pollination of Cycads in the Mesozoic. Current Biology 28: 2806 2812.

Clifford DJ, Carson DM, McKinney DE, Bortiatynski JM, Hatcher PG. 1995. A new rapid technique for the characterization of lignin in vascular plants: thermochemolysis with tetramethylammonium hydroxide (TMAH). Organic Geochemistry 23(2): 169-175. https://doi.org/10.1016/0146-6380(94)00109-E.

Clifford DJ, Hatcher PG, Botto RE, Muntean JV, Anderson KB. 1999. The nature and fate of natural resins in the geosphere. IX Structure and maturation similarities of soluble and insoluble polylabdanoids isolated from Tertiary Class I resinites. Organic Geochemistry 30 (7): 635-650. https://doi.org/10.1016/S0146-6380(99)00018-2.

Coiffard C, Gomez B, Thévenard F. 2007. Early Cretaceous angiosperm invasion of Western Europe and major environmental changes. Annals of Botany 100: 545-553.

Collectif. 2010. Histoire géologique de la Mayenne. Épisode 5 : Mésozoïque. Éditions Errance, pp. 245-248.

Couper RA. 1958. British Mesozoic microspores and pollen grains: a systematic and stratigraphic study. Palaeontographica Abteilung $B$ 103: 75-179.

De Franceschi D, Dejax J, De Ploëg G. 2000. Extraction du pollen inclus dans l'ambre [Sparnacien du Quesnoy (Oise), bassin de Paris] : vers une nouvelle spécialité de la paléo-palynologie. Comptes rendus de l'Académie des sciences, de la terre et des planètes 330: 227-233.

Deák MH, Combaz A. 1967. « Microfossiles organiques » du Wealdien et du Cénomanien dans un sondage de CharenteMaritime. Revue de micropaléontologie 10: 69-96.

Dejax J, De Franceschi D, Lugardon B, De Ploëg G, Arnold V. 2001. Le contenu cellulaire du pollen fossilisé dans l'ambre, préservé à l'état organique. Comptes rendus de l'Académie des sciences, de la terre et des planètes 332: 339-344.

Dettmann ME. 1963. Upper Mesozoic microfloras from southeastern Australia. Proceedings of the Royal Society of Victoria 77: $1-149$.

Dettmann ME, Clifford HT. 1991. Spore morphology of Anemia, Mohria, and Ceratopteris (Filicales). American Journal of Botany 78: 303-325.

Doyle JA, Robbins EI. 1977. Angiosperm pollen zonation of the continental Cretaceous of the Atlantic coastal plain and its application to deep wells in the Salisbury Embayment. Palynology 1: 43-78.

Doyle JA, Endress PK. 2018. Phylogenetic analyses of Cretaceous fossils related to Chloranthaceae and their evolutionary implications. The Botanical Review 84: 156-202.

Durand S, Louail J. 1971. Découverte d'un dépôt cénomanien fossilifère à Neau (Mayenne). Comptes rendus de l'Académie des sciences de Paris 273: 1179-1181. 
Dutta S, Mallick M, Kumar K, Mann U, Greenwood PF. 2011. Terpenoid composition and botanical affinity of Cretaceous resins from India and Myanmar. International Journal of Coal Geology 85(1): 49-55. https://doi.org/10.1016/j.coal.2010.09.006.

Engel MS, Ortega-Blanco J, Azar D. 2011. The earliest earwigs in amber (Dermaptera): a new genus and species from the Early Cretaceous of Lebanon. Insect Systematics and Evolution 42: 139148.

Fensome RA. 1987. Taxonomy and biostratigraphy of schizaealean spores from the Jurassic-Cretaceous boundary beds of the Aklavik Range, District of Mackenzie. Palaeontographica Canadiana 4: 1-49.

Filatoff J. 1975. Jurassic palynology of the Perth Basin, Western Australia. Palaeontographica Abteilung B 154: 1-113.

Fleury R, Polette F, Batten DJ, Durand M, Moreau J-D, Néraudeau D, et al. 2017. Palaeobotanical investigation of a Cenomanian clay lens in Hucheloup quarry, Maine-et-Loire, NW France: taxonomic, stratigraphic and palaeoenvironmental implications. Annales de paléontologie 103: 235-250.

Gingras MK, Maceacher JA, Picherill RK. 2004. Modern perspectives on Teredolites Ichnofacies: observations from Willapa Bay, Washington. Palaios 19: 79-98.

Girard V. 2010. Microcénoses des ambres médio-crétacés français. Taphonomie, systématique, paléoécologie et reconstitution du paléoenvironnement. Mémoires Geosciences Rennes 134: 1-294.

Girard V, Néraudeau D, Breton G, Morel N. 2013a. Palaeoecology of the Cenomanian amber forest of Sarthe (western France). Geologica Acta 11: 321-330.

Girard V, Breton G, Perrichot V, Bilotte M, Le Loeuff J, Nel A, et al. 2013b. The Cenomanian amber of Fourtou (Aude, Southern France): Taphonomy and palaeoecological implications. Annales de paléontologie 99: 301-315.

Gomez B, Martín-Closas C, Barale G, Thévenard F. 2000. A new species of Nehvizdya (Ginkgoales) from the Lower Cretaceous of the Iberian Ranges (Spain). Review of Palaeobotany and Palynology 111: 49-70.

Gomez B, Daviero-Gomez V, Perrichot V, Thévenard F, Coiffard C, Philippe M, et al. 2004. Assemblages floristiques de l'AlbienCénomanien de Charente-Maritime (SO France). Annales de paléontologie 90: 147-159.

Gomez B, Coiffard C, Dépré E, Daviero-Gomez V, Néraudeau D. 2008. Diversity and histology of a plant litter bed from the Cenomanian of Archingeay-Les Nouillers (southwestern France). Comptes Rendus Palevol 7: 135-144.

Grimaldi DA, Peñalver E, Barrón E, Herhold HW, Engel MS. 2019. Direct evidence for eudicot pollen-feeding in a Cretaceous stinging wasp (Angiospermae; Hymenoptera, Aculeata) preserved in Burmese amber. Communications Biology 2: 1-10.

Groot JJ, Groot CR. 1962. Plant microfossils from Aptian, Albian and Cenomanian deposits of Portugal. Comunicações dos Serviços Geológicos de Portugal 46: 133-176.

Heimhofer U, Hochuli PA, Burla S, Weissart H. 2007. New records of Early Cretaceous angiosperm pollen from Portuguese coastal deposits: Implications for the timing of the early angiosperm radiation. Review of Palaeobotany and Palynology 144: 39-76.

Hinkelman J, Vršanská L. 2020. A Myanmar amber cockroach with protruding feces contains pollen and a rich microcenosis. The Science of Nature 107: 19 p. (in press).

Hochuli PA, Heimhofer U, Weissert H. 2006. Timing of early angiosperm radiation: recalibrating the classical succession. Journal of the Geological Society, London 163: 587-594.

Jansonius J, Hills LV. 1976. Genera File of Fossil Spores and Pollen. 3287 cards. Special Publication. Calgary, Canada: Department of Geology, University of Calgary.
Jiang Z, Philippe M, Zhang W, Tian N, Zheng S. 2016. A Jurassic wood that provides insights into the earliest steps in Ginkgo wood evolution. Scientific Reports 6: 38191. https://doi.org/10.1038/ srep38191.

Kramer KU, Green PS. 1990. The families and genera of vascular plants. I. Pteridophytes and Gymnosperms. Berlin: SpringerVerlag, $404 \mathrm{p}$.

Kujau A, Heimhofer U, Hochuli PA, Pauly S, Morales C, Adatte T, et al. 2013. Reconstructing Valanginian (Early Cretaceous) midlatitude vegetation and climate dynamics based on spore-pollen assemblages. Review of Palaeobotany and Palynology 197: 50-69.

Kvaček J. 1999. New data and revision of three gymnosperms from the Cenomanian of Bohemia-Sagenopteris variabilis (Velenovský) Velenovský, Mesenea bohemica (Corda) comb. n. and Eretmophyllum obtusum (Velenovský) comb. n. Acta Musei Nationalis Pragae, Series B, Historia Naturalis 55: 15-24.

Kvaček J. 2000. Frenelopsis alata and its microsporangiate and ovuliferous reproductive structures from the Cenomanian of Bohemia (Czech Republic, Central Europe). Review of Palaeobotany and Palynology 112: 51-78.

Kvaček J, Falcon-Lang HJ, Dašková J. 2005. A new Late Cretaceous ginkgoalean reproductive structure Nehvizdyella gen. nov. from the Czech Republic and its whole-plant reconstruction. American Journal of Botany 92: 1958-1969.

Kvaček J, Doyle P, Endress PK, Daviero-Gomez V, Gomez B, Tekleva M. 2016. Pseudoasterophyllites cretaceus from the Cenomanian (Cretaceous) of the Czech Republic: a possible link between Chloranthaceae and Ceratophyllum. Taxon 65: 1345-1373.

Langenheim JH, Bartlett A. 1971. Interpretation of pollen in amber from a study of pollen in present-day coniferous resin. Bulletin of the Torrey Botanical Club 98: 127-139.

Langenheim JH. 2003. Plant resins: chemistry, evolution, ecology, and ethnobotany. Portland, Oregon, USA: Timber Press.

Lin X, Labandeira CC, Shih C, Hotton CL, Ren D. 2019. Life habits and evolutionary biology of new two-winged long-proboscid scorpion flies from mid-Cretaceous Myanmar amber. Nature Communications 10: 1-14.

Lupia R. 1999. Discordant morphological disparity and taxonomic diversity during the Cretaceous angiosperm radiation: North American pollen record. Paleobiology 25: 1-28.

May F. 1975. Dichastopollennites reticulatus, gen. et sp. nov.: potential Cenomanian Guide Fossil from Soutjern Utah and Northeastern Arizona. Journal of Paleontology 49: 528-533.

Médus J. 1970. Contribution à la classification des grains de pollen du groupe des Circumpolles (Pflug) Klaus. Pollen et Spores 12: 205-216.

Médus J, Triat J-M. 1969. Le Cénomanien supérieur de la coupe de Laudun (Gard, France) : étude palynologique et données sédimentologiques. Review of Palaeobotany and Palynology 9: 213-228.

Mehltreter K, Walker LR, Sharpe JM. 2012. Fern ecology. Cambridge: Cambridge University Press.

Menor-Salván C, Simoneit BRT, Ruiz-Bermejo M, Alonso J. 2016. The molecular composition of Cretaceous ambers: Identification and chemosystematic relevance of 1,6-dimethyl-5-alkyltetralins and related bisnorlabdane biomarkers. Organic Geochemistry 93: 7-21. https://doi.org/10.1016/j.orggeochem.2015.12.010.

Méon H, Guignard G, Pacltová B, Svobodova M. 2004. Normapolles. Comparaison entre l'Europe centrale et du Sud-Est pendant le Cénomanien et le Turonien : évolution de la biodiversité et paléoenvironnement. Bulletin de la Société géologique de France 175: 579-594.

Moreau J-D, Néraudeau D, Gomez B, Tafforeau P, Dépré E. 2014. Plant inclusions from the Cenomanian flints of Archingeay-Les Nouillers, western France. Lethaia 47: 313-322. 
Moreau J-D, Néraudeau D, Philippe M, Dépré E. 2017. Albian flora from Archingeay-Les Nouillers (Charente-Maritime): comparison and synthesis of Cretaceous meso- and macro-remains from the Aquitaine Basin (southwestern France). Geodiversitas 39: 729740 .

Néraudeau D, Perrichot V, Dejax J, Masure E, Nel A, Philippe M, et al. 2002. Un nouveau gisement à ambre insectifère et à végétaux (Albien terminal probable) : Archingeay (Charente-Maritime, France). Geobios 35: 233-240.

Néraudeau D, Allain R, Perrichot V, Videt B, De Broin F, Guillocheau $\mathrm{F}$, et al. 2003. Découverte d'un dépôt paralique à bois fossiles, ambre insectifère et restes d'Iguanodontidae (Dinosauria, Ornithopoda) dans le Cénomanien inférieur de Fouras (CharenteMaritime, sud-ouest de la France). Comptes Rendus Palevol 2: 221-230.

Néraudeau D, Vullo R, Gomez B, Perrichot V, Videt B. 2005. Stratigraphie et paléontologie (plantes, vertébrés) de la série margino-littorale Albien terminal - Cénomanien basal de TonnayCharente (Charente-Maritime, France). Comptes Rendus Palevol 4: 79-93.

Néraudeau D, Perrichot V, Colin J-P, Girard V, Gomez B, Guillocheau $\mathrm{F}$, et al. 2008. A new amber deposit from the Cretaceous (uppermost Albian-lowermost Cenomanian) of SW France. Cretaceous Research 29: 925-929.

Néraudeau D, Vullo R, Gomez B, Girard V, Lak M, Videt B, et al. 2009. Amber, plant and vertebrate fossils from the Lower Cenomanian paralic facies of Aix Island (Charente-Maritime, SW France). Geodiversitas 31: 13-28.

Néraudeau D, Redois F, Ballèvre M, Duplessis B, Girard V, Gomez B, et al. 2013. L'ambre cénomanien d'Anjou: stratigraphie et paléontologie des carrières du Brouillard et de Hucheloup (Ecouflant, Maine-et-Loire). Annales de paléontologie 99: 361374. https://doi.org/10.1016/j.annpal.2013.10.001.

Néraudeau D, Saint Martin S, Batten DJ, Colin J-P, Daviero-Gomez V, Girard V, et al. 2016. Palaeontology of the upper Turonian paralic deposits of the Sainte-Mondane Formation, Aquitaine Basin, France. Geologica Acta 14: 53-69.

Néraudeau D, Perrichot V, Batten D, Boura A, Girard V, Jeannau L, et al. 2017. Upper Cretaceous amber from Vendée, north-western France: Age dating and geological, chemical, and palaeontological characteristics. Cretaceous Research 70: 77-95.

Nohra YA, Perrichot V, Jeanneau L, Le Pollès L, Azar D. 2015. Chemical characterization and botanical origin of French Ambers. Journal of Natural Products 78(6): 1284-1293. https://doi.org/ 10.1021/acs.jnatprod.5b00093.

Otto A, Simoneit BRT. 2002. Biomarkers of Holocene buried conifer logs from Bella Coola and north Vancouver, British Columbia, Canada. Organic Geochemistry 33(11): 1241-1251. https://doi. org/10.1016/S0146-6380(02)00139-0.

Peris D, Pérez-de la Fuente R, Peñalver E, Delclòs X, Barrón E, Labandeira CC. 2017. False Blister Beetles and the expansion of gymnosperm-insect pollination modes before Angiosperm dominance. Current Biology 27: 1-8.

Perrichot V. 2005. Environnements paraliques à ambre et végétaux du Crétacé Nord-Aquitain (Charentes, Sud-Ouest de la France). Mémoires Géosciences Rennes 118: 1-310.

Peyrot D, Barrón E, Polette F, Batten DJ, Néraudeau D. 2019. Early Cenomanian palynofloras and inferred resiniferous forests and vegetation types in Charentes (southwestern France). Cretaceous Research 94: 168-189.

Philippe M. 1995. Bois fossiles du Jurassique de Franche-Comté (nord-est de la France) : systématique et biogéographie. Palaeontographica Abteilung B 236(1/3): 45-103.
Philippe M, Bamford M. 2008. A key to morphogenera used for Mesozoic conifer-like woods. Review of Palaeobotany and Palynology 148: 184-207.

Pocock SAJ. 1972. Palynology of the Jurassic sediments of Western Canada. Part 2. Marine species. Palaeontographica Abteilung $B$ 137: 85-153.

Poinar GO Jr. 1992. Life in amber. Stanford University Press, 368 p.

Poinar GO Jr. 2010. Cascoplecia insolitis (Diptera: Cascopleciidae), a new family, genus, and species of flower-visiting, unicorn fly (Bibionomorpha) in Early Cretaceous Burmese amber. Cretaceous Research 31: 71-76.

Polette F. 2019. Les assemblages palynologiques continentaux du Crétacé inférieur de France (Tithonien-Cénomanien) : paléoenvironnements, paléoclimats, stratigraphie, et taxinomie. Thèse, université de Rennes, 2 tomes, 592 p. (inédit).

Polette F, Licht A, Cincotta A, Batten DJ, Depuydt P, Néraudeau D, et al. 2019. Palynological assemblage from the lower Cenomanian plant-bearing Lagerstätte of Jaunay-Clan Ormeau-Saint-Denis (Vienne, western France): stratigraphic and paleoenvironmental implications. Review of Palaeobotany and Palynology 271: 1-21.

Pons D, Boureau E, Broutin J. 1976. Nouvelles études paléobotaniques des environs d'Angers I. Eretmophyllum andegavense nov. sp., ginkgoale fossile du Cénomanien. In: Comptes rendus $d u 97^{e}$ Congrès national des Sociétés savantes. Section Sciences, Nantes, pp. 367-369.

Pons D. 1979. Les organes reproducteurs de Frenelopsis alata (K. Feistm) Knobloch, Cheirolepidiaceae du Cénomanien de l'Anjou, France. In: Comptes rendus du $104^{e}$ Congrès national des Société savantes. Section Sciences, Bordeaux, pp. 209-231.

Proctor MCF, Tuba Z. 2002. Poikilohydry and homoihydry: antithesis or spectrum of possibilities? New Phytologist 156: 327-349.

Rasband WS. 1997-2013. ImageJ. Bethesda, Maryland, USA: U.S. National Institutes of Health. http://rsb.info.nih.gov/ij/.

Ravn RL. 1995. Miospores from the muddy sandstone (upper Albian), wind river basin, Wyoming, USA. Palaeontographica Abteilung $B$ 234: 41-91.

Ravn RL, Witzke BJ. 1995. The palynostratigraphy of the Dakota Formation (?Late Albian-Cenomanian) in its type area, northwestern Iowa and northeastern Nebraska, USA. Palaeontographica Abteilung B 234: 93-171.

Redois F, Durand M, Fleury R, Mellier B, Moreau J-D, Néraudeau D, et al. 2016. Les argiles ligniteuses du Cénomanien de Hucheloup (Ecouflant, Maine-et-Loire). In: Colloque $d u$ Groupe français $d u$ Crétacé, Musée Vert, avril 2016, Le Mans, pp. 75-76.

Rusea G, Claysius K, Runi S, Joanes U, Haja Maideen KM, Latiff A. 2009. Ecology and distribution of Lycopodiaceae Mirbel in Malaysia. Blumea 54: 269-271.

Saint Martin J-P, Saint Martin S. 2018. Exquisite preservation of a widespread filamentous microorganism from French Cretaceous ambers: a key for review of controversial fossil. Comptes Rendus Palevol 17: 415-434.

Saint Martin S, Saint Martin J-P, Girard V, Grosheny D, Néraudeau D. 2012. Filamentous micro-organisms in Upper Cretaceous amber (Martigues, France). Cretaceous Research 35: 217-229.

Saint Martin S, Saint Martin J-P, Girard V, Néraudeau D. 2013a. Organismes filamenteux de l'ambre du Santonien de Belcodène (Bouches-du-Rhône, France). Annales de paléontologie 99: 339 360.

Saint Martin J-P, Saint Martin S, Néraudeau D. 2013b. L'ambre associé aux lignites cénomaniens du Sarladais (Dordogne, SO France). Annales de paléontologie 99: 289-300.

Samuel E, Gaillard MG. 1984. Les gisements à flore fossile d'âge Crétacé supérieur en France : localisation, stratigraphie et essai de 
corrélations des données macro- et microfloristiques. Bulletin mensuel de la Société linnéenne de Lyon 53 ${ }^{\mathrm{e}}$ année 6: 213-223.

Schmidt AR, Schäfer U. 2005. Leptotrichites resinatus new genus and species: a fossil sheathed bacterium in Alpine Cretaceous amber. Journal of Paleontology 79: 175-184.

Schrank E. 2010. Pollen and spores from the Tendagru Beds, Upper Jurassic and Lower Cretaceous of southeast Tanzania: palynostratigraphical and paleoecological implications. Palynology 34: 3-42.

Singh C. 1971. Lower Cretaceous microfloras of the Peace River area, Northwestern Alberta. Bulletin of the Research Council of Alberta Bulletin 28: 1-522.

Singh C. 1983. Cenomanian microfloras of the Peace River area Northwestern Alberta. Bulletin of the Research Council of Alberta Bulletin 44: 1-322.

Smith AR, Pryer KM, Schuettpelz E, Korall P, Schnieifer H, Wolf PG. 2006. A classification of extant ferns. Taxon 55: 705-731.

Steart DC, Strullu-Derrien C, Philippe M, Krieger J, Stevens L, Spencer ART, et al. 2020 (submitted). New evidence of the architecture and affinity of fossil trees from the Jurassic Period Purbeck Forests of southern England.

Thévenard F, Gomez B, Daviero-Gomez V. 2005. Xeromorphic adaptations of some Mesozoic gymnosperms. A review with paleoclimatological implications. Comptes Rendus Palevol 4: 6777.

Vakhrameev VA, Doludenko MP. 1977. The Middle-Late Jurassic boundary, an important threshold in the development of climate and vegetation of the Northern Hemisphere. International Geology Review 19: 621-632.

Van Konijnenburg-Van Cittert JHA. 1971. In situ gymnosperm pollen from the Middle Jurassic of Yorkshire. Acta Botanica Neerlandica 20: 1-97.

Van Konijnenburg-Van Cittert JHA. 2002. Ecology of some Late Triassic to Early Cretaceous ferns in Eurasia. Review of Palaeobotany and Palynology 119: 113-124.

Waksmundzka M. 1981. Palynological analysis of Lower Cretaceous sediments from Kujawy (Poland). Acta Paleontologica Polonica 26: $257-280$.

Walker JW, Walker A. 1984. Ultrastructure of Lower Cretaceous angiopserm pollen and the origin and early evolution of flowering plants. Annals of the Missouri Botanical Garden 71: 464-521.

Wetzel W. 1953. Mikropaläontologische Untersuchung des schleswigholsteinischen Bernsteins. Neues Jahrbuch für Geologie und Paläontologie H7: 11-321.

Cite this article as: Néraudeau D, Saint Martin J-P, Saint Martin S, Jeanneau L, Moreau J-D, Philippe M, Polette F, Gendry D, Brunet J, Tréguier J. 2020. Amber- and plant-bearing deposits from the Cenomanian of Neau (Mayenne, France), BSGF-Earth Sciences Bulletin 191: 39. 